\title{
DESARROLLO Y VIGENCIA DE LOS DERECHOS Y GARANTIAS EN DIEZ AÑOS DE REGIMEN CONSTITUCIONAL (1980-90)
}

Francisco José Eguiguren Praeli

“. . . Los problemas constitucionales no son, primariamente, problemas de Derecho sino de poder; la verdadera Constitución de un país sólo reside en los factores reales y efectivos de poder que en ese país rigen; $y$ las Constituciones escritas no tienen valor ni son duraderas más que cuando dan expresión fiel a los factores de poder imperantes en la realidad social. .."

Ferdinand Lassalle: ¿Qué es una Constitucion? Ariel (1976): p. 97.

En el Perú hemos tenido muchas constituciones pero muy poca constitucionalidad, como lo demuestran casi una docena de constituciones que en su gran mayoría no pasaron de ser simples "hojas de papel" (para usar la expresión de Lassalle) y una tradición política caracterizada por la inestabilidad, el autoritarismo y la alternancia pendular de regímenes formalmente democráticos y gobiernos de facto. Ello al parecer ha acostumbrado a los peruanos a percibir como algo natural e inevitable la existencia de una marcada distancia entre los postulados y preceptos contenidos en los textos constitucionales, con respecto a sus niveles de aplicación concreta y vigencia efectiva en la realidad.

A lo largo de nuestra experiencia republicana, las normas constitucionales han aparecido como notoriamente incapaces de encuadrar el desenvolvimiento del proceso político, para encauzarlo hacia la construcción y el afianzamiento de una sociedad democrática. De allí que al cumplirse los primeros diez años 
de régimen constitucional y de continuidad democrática, estamos asistiendo a un hecho verdaderamente excepcional en nuestro país. La Carta de 1979 (vigente desde el 28 de julio del 80) ha tenido la virtud de brindar el marco político y jurídico para la instalación y culminación de dos gobiernos electos por el pueblo en comicios inobjetables, así como para la elección consecutita (en 1990) de un tercer gobierno también emanado de la voluntad popular. Fllo configura una situación singular y sin precedentes en la accidentada vida politica nacional.

Indudablemente se trata de un logro muy importante, pues denota avances en el aún incipiente proceso de afianzamiento de la institucionalidad democrática y constitucional en el país. Pero lo paradójico es que su consecución se produce precisamente en momentos que el Pirú afronta un cuadro dramático de violencia política y social generalizada, así como los estragos de una profunda crisis económica, fenómenos que se han ido acrecentando durante los últimos años y que, sin duda, convierten en más arduo, penoso e incierto el irrenunciable esfuerzo por construir una sociedad democrática en nuestra patria.

Sería absurdo culpar exclusivamente a los anteriores textos constitucionales de la fragilidad y el fracaso que acompañaron a la gran mayoría de intentos de establecer un régimen democrático en el pais: pero también resulta errado creer que en ello no les ha cabido alguna responsabilidad importante. Y es que toda Constitución. tanto en su contenido como en sus niveles de viabilidad, está profundamente condicionada por los factores de poder político, aspiraciones y conflictos imperantes en la sociedad, así como por los intereses de los grupos dominantes y la presión de los sectores sociales. La influencia de estos elementos, presentes en el proceso de claboración de la Constitución del 79 y en su aplicación durante diez años de régimen democrático, explica en mucho que haya resultado posible una situación que no pudo darse en las experienciats políticas precedentes.

Es por cllo que para realizar una somera evaluación del desarrollo y vigencia que han correspondido a los derechos y garantías a lo largo de estos diez años de régimen constitucional, resulta 
indispensable analizar y confrontar el modelo político expresado en la Carta del 79 con la aplicación concreta que le ha correspondido a lo largo de dos gobiernos elegidos democráticamente. Así podremos apreciar los avances, limitaciones y deficiencias presentes en el periodo, a fin de determinar en qué medida se ha acrecentado o reducido aquella distancia inicial existente entre el modelo normativo y la realidad.

Este análisis debe además permitir ofrecer algunos elementos de reflexión en torno a los principales retos y dificultades que pueden vislumbrarse para la continuidad y el desarrollo de las instituciones constitucionales y democráticas, en vísperas del inicio de un nuevo gobierno emanado de la voluntad popular, particularmente cuando el país atraviesa uno de sus trances más delicados e inciertos.

\section{EL MODELO POLITICO DE LA CONSTITUCION DE 1979}

\subsection{La importancia del proceso constituyente y de la elaboración} de la Carta de 1979

Las circunstancias políticas y sociales que rodearon el proceso constituyente, así como las condiciones particulares en que se realizó la tarea de elaboración de la Carta del 79, han ejercido notable influencia en el contenido del modelo global de dicha Constitución y en el importante grado de aceptación logrado por esta norma fundamental en la mayoría de las fuerzas políticas.

Debe tenerse presente que la Asamblea Constituyente que elaboró la Carta del 79 fue electa en 1978 por votación popular libre y directa, instalándose y realizando su labor en el último tramo del "Gobierno Revolucionario de la Fuerza Armada" (1968-80) precisamente cuando el régimen militar había abandonado sus iniciales banderas reformistas y respondía con serias restricciones de las libertades públicas a las demandas populares ante las primeras manifestaciones de la crisis económica, así como a los crecientes reclamos de las distintas fuerzas políticas en favor de la apertura democrática y la realización de elecciones generales. El control gubernamental ejercido sobre los medios de comunica- 
ción social (diarios, televisión y radio), la represión a los grandes paros nacionales y la clausura de revistas independientes, con detenciones y deportaciones, sólo sirvieron para demostrar el agotamiento del modelo político del gobierno militar y su marcado aislamiento frente a los partidos políticos y los sectores populares.

Fue así que en el segundo semestre de 1977, luego de un importante paro nacional, el gobierno de la Fuerza Armada anunció su voluntad de emprender el tránsito hacia un régimen constitucional elegido democráticamente por la población, para lo cual confeccionó un "cronograma de transferencia" que incluía la realización de elecciones para conformar una Asamblea Constituyente, en junio de 1978, la elaboración por ésta de una nueva carta constitucional en el período de un año (julio 78 a julio 79 ) y el desarrollo de elecciones presidenciales y parlamentarias en 1980 . de donde surgiría un nuevo gobierno que asumiría el poder el 28 de julio de ese año (1).

La mayoría de agrupaciones políticas (viejos y nuevos partidos y frentes) aceptaron estas reglas de juego, con las excepciones de Acción Popular y Patria Roja, que rechazaron el tránsito previo por una Asamblea Constituyente demandando la realización de elecciones generales; ambos grupos si participaron ulteriormente en los comicios del 80 .

Luego de diez años de dictadura, con ausencia de ejercicio del derecho de sufragio y fuertes restricciones de las libertades políticas, la realización de elecciones y el desarrollo de la elaboración del tex to constitucional en el marco de un gobierno de facto. confirieron a dichos procesos algunas características muy especiales, las cuales no sólo estuvieron presentes en la campaña electoral sino que, a la postre, también influyeron en el comportamiento de lis Asamblea Constituyente y en el contenido final de la Carta de 1979. En cuanto a las características del proceso electoral constituyente, cabe señalar las siguientes:

(1) Cfr. BERNALES ENRIQUE, Crisis politica: ¿Solucion electoral?. DES$\mathrm{CO}, 1980,132 \mathrm{pp}$; interesante trabajo que ofrece importantes elementos de información y análisis sobre el proceso político en que se enmarcó la elección de la Asamblea Constituyente. 
a) Las elecciones para la asamblea constituyente crearon un espacio de relativa apertura política para la reaparición de los partidos y fuerzas políticas en la vida nacional. El contenido predominante del mensaje en la campaña electoral estuvo fundamentalmente orientado por una fuerte reacción antimilitar y anti autoritario, sirviendo ante todo como canal de expresión para las críticas al régimen de facto, que habían venido siendo permanentemente acalladas y reprimidas por éste.

b) Como las elecciones para la Asamblea Constituyente se realizaron con relativa cercanía al anunciado cambio de gobierno, ello determinó que los partidos y los candidatos optaran fundamentalmente por instrumentar dicho proceso con miras a los comicios del 80 , antes que abocarse con mayor esmero a la formulación de propuestas concretas para la futura Constitución (2). La ocasión resultó más bien propicia para recomponer o crear los aparatos partidarios, difundir planteamientos ideológicos y ofertas políticas, promocionar candidaturas personales de futuros postulantes a parlamentarios y medir el respaldo electoral de cada fuerza.

c) Pese a las auto exclusiones de Acción Popular y Patria Roja, las fuerzas que compitieron en la elección para la Asamblea Constituyente conformaron un espectro político bastante amplio y plural en las tendencias y propuestas formuladas en el debate: esta pluralidad también quedó confirmada en la ulterior composición de la asamblea electa por el pueblo, lo cual influyó en el contenido final de la Constitución que ella elaboró.

La campaña electoral se desarrolló con bastante amplitud en cuanto al acceso otorgado a los partidos para la utilización de los medios de comunicación social, que en aquel entonces controlaba el gobierno. Sin embargo, algunas organizaciones de izquierda y

(2) Cfr. ENRIQUE BERNALES B. y MARCIAL RUBIO C.: Constitución: fuentes e interpretación. Mesa Redonda Editores, (1988) 354 pags. Este importante trabajo permite constatar que muy pocos partidos (la mayoría de izquierda) se preocuparon al menos de elaborar previamente un anteproyecto de Constitución. 
sus dirigentes, debido a su participación en el paro nacional del 22 y 23 de mayo del 78 y a las críticas que formularon contra el régimen militar, fueron objeto de persecución, detenciones y deportaciones.

d) Entre los hechos políticos más novedosos y trascendentes, cabe mencionar el inicio de la participación electoral de la "joven izquierda" surgida en las décadas del 60 y 70 , que anteriormente había recusado la intervención dentro de los mecanismos de la democracia formal. Lo importante de esta situación radica en cl alto volumen de votos que lograron en conjunto las diversas agrupaciones de izquierda, cerca del $30 \%$, fenómeno que marcabal el inicio de una nueva correlación de fuerzas en el espectro político y electoral peruano. Simultáneamente, las elecciones marcaron la virtual desaparición de los partidos de derecha de corte más tradicional y oligárquico.

Otro aspecto de importancia fue la modificación de la normatividad relativa a la edad para acceder a la ciudadanía y al ejercicio del derecho de sufragio, que se redujo de 21 a 18 años. Esta medida fue positiva porque amplió el cuerpo electoral, adecuándose a la realidad demográfica y económica del país; sin embargo, se mantuvo la injusta y anacrónica exclusión del derecho de sufragio a los analfabetos, prohibición que quedó suprimida recién con la Constitución del 79.

En cuanto a la actuación de la Asamblea Constituyente en liı elaboración de la Carta, las principales características del desarrollo de su labor fueron (3):

a) La composición política pluralista de la asamblea constituyente, resultó fundamental para que en el debate y el desempeño

(3) Cfr. EGUIGUREN PRAELI, FRANCISCO: I.u Cunstitución Peruana de 1979. La dificil (e incierta) distancia entre 'l modelo normativo y' su aplicación en la realidad; en : La Constitucion Politica de 1979 y sus problemas de aplicación, Francisco Eguiguren (disctor), Cultural Cuzco S.A., Lima $1987 ;$ p. 5 a 16. 
de esta labor tuvieran expresión amplias tendencias ideológicas, correspondientes a los diversos grupos que estuvieron presentes. Ello fue muy positivo tanto para la representatividad del cuerpo constituyente, como para la pluralidad de aportes y propuestas que en buena medida recogió la Carta elaborada.

b) En la composición política de la asamblea, el Partido Aprista fue la primera fuerza con 37 de los 100 representantes; el Partido Popular Cristiano contó con 25 y las diversas agrupaciones de izquierda conformaron un bloque de 28 representantes (Partido Comunista 6, Partido Socialista Revolucionario 6, FOCEP 12, y UDP 4). El 10\% restante estuvo integrado por el FRENATRACA (4), la Democracia Cristiana (2), la UNO (2) y el MDP (2); cuyos representantes establecieron acuerdos con los distintos bloques en función de sus propias inclinaciones políticas y de votaciones concretas.

El hecho que ningún partido o fuerza representados en la asamblea hubiera logrado por sí solo contar con una mayoría absoluta, propició y determinó que se buscaran y establecieran formas de entendimiento y transacción, con concesiones recíprocas entre los distintos bloques de centro (APRA), derecha (PPC) e izquierda, a fin de obtener el acuerdo necesario para que algunas normas o propuestas llegaran a plasmarse en el texto de la Constitución. Ello sin duda ha resultado muy importante para el significativo grado de consenso y legitimidad política alcanzado en los supuestos fundamentales de la Carta del 79.

c) El régimen militar no interfirió mayormente en el desarrollo de la tarea constituyente, lo que favoreció el proceso de elaboración de la Carta y creó buenas condiciones para el tránsito hacia un nuevo gobierno elegido por el pueblo. No existió en la asamblea un partido que asumiera la calidad de vocero del oficialismo y de sus planteamientos; sin embargo, el Partido Aprista mantuvo en dicho lapso vínculos bastante estrechos con el gobierno militar, tal vez porque al pensarse triunfador en las elecciones generales del 80, deseó evitar cualquier conflicto serio que pudiera haber amenazado el proceso de transferencia. 
d) La cercanía de las elecciones generales distrajo la atención de los partidos y de la mayor parte de asambleístas, quienes lucieron más interesados en realizar la campaña que los pudiera llevar a integrar el futuro parlamento. Sólo unos pocos representantes constituyentes de los diversos grupos (conforme aparece en las actas de los debates) se abocaron con interés y dedicación a la tarea de elaborar una nueva Constitución.

A ello hay que agregar la inexperiencia y la poca formación técnica en materia jurídica de que adolecían muchos de los constituyentes. Si a todo esto sumamos la ausencia de un anteproyecto de Constitución que sirviera de base a la labor constituyente, entenderemos mejor el poco brillo y escasa profundidad que, en general, caracterizaron al debate destinado a formular la Carta. Sin embargo, lo dicho también debe llevar a resaltar el esfuerzo de quienes aportaron con mayor entusiasmo y seriedad a la elaboración de la Constitución del 79 y hace más meritorio el resultado final plasmado en el contenido de esta norma.

\subsection{El modelo global de la Constitución Peruana del 79}

"La Constitución es, en cuanto pretensión fundacional del Estado y de las reglas básicas de la sociedad, una ley no sujeta necesariamente al consenso de todos los sectores económicos y políticos sino, fundamentalmente, de quienes expresan en el acto constituyente la capacidad de generalizar su percepción del Estado y la sociedad, imponiéndola como decisión. Así pues, la Constitución contiene necesariamente un modelo de sociedad que se expresa en tres ordenamientos concatenados: el sistema económico, el sistema político y los derechos ciudadanos".

MARCIAL RUBIO y ENRIQUE BERNALES: Constitución.y sociedad política. Mesa Redonda Edit.; Lima 1983; pág. 020.

La Constitución Peruana de 1979, como no podía ser de otro modo, expresa en su tex to un cierto modelo global de sociedad, que queda definido por un conjunto de decisiones, principios y aspiraciones de tipo político, ideológico y socio económico. En base a dicho modelo se configura una determinada forma de con- 
cebir y organizar la sociedad y las relaciones sociales, la estructura del Estado con el papel y funciones asignadas a sus distintos órganos, los alcances de los derechos y libertades de los ciudadanos, las reglas de juego impuestas a los agentes económicos y las fuerzas políticas, así como el tipo de vinculación y control establecido entre gobernantes y gobernados.

La plural composición de la asamblea constituyente y la correlación de fuerzas imperante en ella, que forzó a la realización de concesiones y acuerdos entre los partidos, tuvieron la gran virtud de incidir en que el modelo global contenido en la Constitución de 1979 luciera bastante más cercano al nuevo rostro político del país. Pero estas transacciones políticas determinaron también que el modelo global plasmado en el texto constitucional articule diversos principios y normas que no siempre guardan la suficiente coherencia y complementariedad.

Para sintetizar, de manera bastante esquemática, el modelo global plasmado en la Constitución Peruana del 79, puede decirse que en general contiene algunos conceptos y fundamentos esenciales del llamado "Estado Social y Democrático de Derecho", los que resultan relativizados o complejizados al articularse con otros postulados y principios que crean ciertas contradicciones y potenciales incoherencias, las mismas que conspiran contra la armonía del modelo y pueden amenazar su viabilidad.

Es así que nuestra Constitución combina una amplia y positiva relación de derechos y libertades, propia de una democracia social avanzada, al lado de una opción mayormente neoliberal en materia del régimen económico, con una intervención estatal bastante atenuada y la relativa carencia de instrumentos importantes para encauzar y controlar la tenencia y el uso de la propiedad así como el ejercicio de la actividad empresarial, a fin de que se orienten hacia la satisfacción de necesidades de tipo social. Estos aspectos pueden tornar en inviables muchos de los derechos económicos y sociales plasmados en la Carta, que aparecen como simples enunciados cuyo contenido y alcances concretos han quedado supeditados a una ulterior regulación por vía de la ley; otros se han consignado de manera declarativa, ante todo como normas 
programáticas que deben inspirar las decisiones políticas y legislativas de los gobiernos, pero desprovistos de mecanismos que permitan acceder a ellos o exigir su realización en el corto plazo.

Este modelo se completa, en el marco político, con los elementos centrales de una democracia representativa tradicional y ciertamente restringida, que carece de canales de participación popular distintos al sufragio para la elección periódica de representantes. A su vez, conserva un régimen híbrido donde coexisten instituciones propias de los sistemas presidencial y parlamentario, aunque con acentuada tendencia al fortalecimiento del Poder Ejecutivo (en sus atribuciones legislativas, económicas y políticas) pero manteniendo la responsabilidad política de los ministros ante el parlamento.

A continuación presentamos los lineamientos principales adoptados por la Constitución en materia del sistema político, el régimen económico y el tratamiento de los derechos constitucionales.

a) El sistema político. La Constitución proclama como sistema político la democracia representativa, a la que se atribuye cilrácter social y basamento en el trabajo, donde el sufragio de los ciudadanos es la fuente del poder y autoridad que ejercen el Presidente de la República, los parlamentarios y los miembros de los gobiernos municipales y regionales. Sin embargo, la participación popular queda circunscrita únicamente al voto en las elecciones periódicas, sin que existan mecanismos adicionales de democracia semi-directa que permitan intervenir a la población en el proceso de adopción o ratificación de las decisiones políticas del Estado, ni en la formulación de iniciativas legislativas. Entre elección y elección, el pueblo carece también de toda posibilidad para controlar o renovar el mandato conferido a los gobernantes y a las autoridades electas.

Un rasgo importante del régimen político adoptado, es la clara tendencia al fortalecimiento de las atribuciones del Presidente de la República. En el campo de la producción normativa, el Presidente cuenta con iniciativa legislativa (a través de proyectos 
de ley), siendo a quien corresponde promulgar y mandar publicar las leyes aprobadas por el Congreso, las que incluso puede observar ejerciendo una suerte de "veto suspensivo"; también puede convocar al Congreso para la realización de legislaturas extraordinarias. E1 Parlamento puede delegar al Poder Ejecutivo facultades legislativas en materias específicas y por tiempo determinado; sin perjuicio de la atribución conferida al Presidente para dictar medidas extraordinarias en materia económica y financiera ante situaciones de emergencia o urgencia (art. 211o. inc. 20). Además, el Poder Ejecutivo ejerce la potestad reglamentaria de las leyes.

El Presidente y el Poder Ejecutivo han recibido en la nueva Constitución importantes atribuciones y funciones en materia económica, tales como la elaboración del proyecto anual de Presupuesto Público, que luego es presentado al Congreso, y la regulación de los aranceles. Además, el Presidente es el Jefe Supremo de las Fuerzas Armadas y de la Policía Nacional, dirigiendo el Sistema de Defensa y teniendo bajo su competencia velar por el control del orden interno y la seguridad exterior de la República; también tiene a su cargo la conducción de la política exterior y de las relaciones internacionales del Estado.

El Presidente cuenta con un Consejo de Ministros, a cuya cabeza se encuentra un presidente o premier cuyas atribuciones son inferiores a las del primer ministro de un régimen parlamentario; son nulos los actos del Presidente de la República que no cuenten con refrendo ministerial. Los ministros son designados y removidos por el Presidente (con acuerdo del Presidente del Consejo), siendo políticamente responsables ante la Cámara de Diputados por su gestión y por los actos presidenciales que refrendan. Cuando dicha cámara aprueba un voto de censura o falta de confianza en contra de algún ministro, éste queda obligado a renunciar; si dicho voto se aprueba contra el Consejo o el primer ministro, todos ellos deben dimitir.

Tanto el Presidente como sus ministros tienen responsabilidad penal y constitucional por los delitos que cometan en el ejercicio de sus funciones o por las infracciones de la Constitución en que incurran, contando con el privilegio del antejuicio (o juicio 
político) que debe realizarse mediante un procedimiento que involucra a ambas cámaras del Congreso, quienes deciden si procede su sometimiento a juicio ante la Corte Suprema. En el caso del Presidente, éste sólo puede ser acusado durante su mandato por unas pocas causales previstas en el Art. 210o. de la Constitución, que son traición a la patria; por impedir las elecciones generales, regionales o locales; por disolver el Congreso, salvo cuando medie censura de tres Consejos de Ministros; o por impedir el funcionamiento del Jurado Nacional de Elecciones y del Tribunal de Garantías Constitucionales.

El Congreso es el titular de la potestad legislativa y cuenta con dos cámaras, una de Diputados y otra de Senadores, que cumplen funciones colegislad oras. La Cámara de Diputados tiene $180 \mathrm{miem}-$ bros, que se eligen por departamentos según la densidad electoral de cada circunscripción; la Cámara de Senadores consta de 60 miembros, además de los ex-presidentes de la República de gobiernos constitucionales, que son Senadores Vitalicios. Actualmente los senadores son elegidos a nivel nacional por distrito electoral único, pero la Carta prevé que cuando queden conformadas las regiones serán estas quienes elijan a los representantes al Senado.

La a tribución para interpelar o censurar ministros corresponde exclusivamente a la Cámara de Diputados; el Presidente puede disolver dicha Cámara cuando ésta ha derribado a tres consejos de ministros. El Senado, en cambio, tiene a su cargo la ratificación del nombramiento de altos funcionarios designados por el Poder Ejecutivo, tales como embajadores, generales de las FF.AA. y Policía, presidente del Banco Central de Reserva, etc. El mandato parlamentario es irrenunciable y no está sujeto a revocación popular; tampoco existe renovación parcial de los miembros del Congreso. Los parlamentarios gozan de inmunidades y prerrogativas para garantizar el mejor desempeño de su labor; la única función pública que pueden ejercer simultáneamente es la de ministro.

Un aspecto novedoso de la Carta del 79 es que, al lado de los clásicos poderes Ejecutivo, Legislativo y Judicial, contempla la existencia no subordinada a éstos de órganos autónomos, como el 
Ministerio Público, el Tribunal de Garantías Constitucionales, el Jurado Nacional de Elecciones, el Banco Central de Reserva, la Contraloría, la Superintendencia de Banca y Seguros, etc.

b) Los derechos y garantías constitucionales. Los constituyentes pusieron especial esmero en proclamar la primacía de la persona humana como valor y principio esencial de todo el ordenamiento constitucional y democrático, incorporando en la Carta los avances contenidos en los pactos internacionales sobre Derechos Humanos.

Es así que se reconocen derechos esenciales de la persona, tales como la libertad física y ambulatoria, libertad de reunión, integridad personal, inviolabilidad del domicilio y las comuniciciones, libertad de conciencia, expresión e información, derecho al honor y la buena reputación, a la propia imagen y a la intimidad personal. Resulta novedosa e importante la consagración constitucional de derechos del detenido en la etapa policial, quien no puede ser indebidamente incomunicado, ni privado de la asistencia de un abogado o ser sometido a torturas y maltratos; asimismo de derechos del procesado y de garantías de la administración de justicia.

En cuanto al sufragio, la carta concede su ejercicio desde los 18 años y elimina la injusta exclusión de este derecho que anteriormente estaba impuesta a los analfabetos; a la vez, mantiene la privación del derecho de elegir o ser elegido a los miembros de las Fuerzas Armadas y la Policía Nacional, mientras se encuentran en el servicio activo.

También son recogidos constitucionalmente derechos propios de la familia, tales como el matrimonio y el reconocimiento de derechos patrimoniales a quienes forman uniones familiares de hecho; al lado de otros derechos de naturaleza social, como la salud, educación, seguridad social y bienestar, vivienda y alimentación. Asimismo derechos de naturaleza económica, como la propiedad, la libertad de contratación, de comercio y empresa; a la par de derechos laborales como la libertad de trabajo, la remuneración 
justa, la estabilidad en el empleo, la sindicalización, la huelga, la negociación colectiva, etc. En el campo educativo, cultural y científico, destacan la libertad de educación, la gratuidad de la enseñanza impartida por el Estado, la autonomía universitaria, la libertad de cátedra, los derechos de los grupos nativos y etnías a preservar su lengua, valores y costumbres.

Para proteger estos importantes derechos, la Constitución contempla un sistema bastante completo de jurisdicción constitucional y garantias, donde el Habeas Corpus está previsto para preservar la libertad personal y el Amparo para todos los demás derechos. Ambas garantías proceden frente a amenazas o violaciones de los derechos, pudiendo interponerse contra los actos u omisiones provenientes de autoridades, funcionarios o de personas particulares. A su vez, el control de la constitucionalidad de las leyes y de las normas se efectúa a través de la acción de inconstitucionalidad ante el Tribunal de Garantías Constitucionales y la acción popular ante el Poder Judicial, sin perjuicio del control difuso que puede realizar cualquier juez en todo proceso judicial.

El sistema de protección de los derechos humanos y la constitucionalidad se complementa con el establecimiento del Ministerio Público, como defensor del pueblo, de la legalidad y de los derechos ciudadanos; aunque simultáneamente desempeña las funciones de titular de la acción penal y de la acusación en nombre de la sociedad. Además, el Tribunal de Garantías Constitucionales es encargado de conocer directamente de las acciones de inconstitucionalidad, y de ejercer la casación de las resoluciones de Habeas Corpus o Amparo que previamente hayan sido desestimadas por el Poder Judicial.

c) El sistema económico. Aspecto importante y novedoso en el país, ha sido la incorporación en la Carta del 79 de un tratamiento sistemático y amplio del Régimen Económico (lo que la moderna doctrina denomina "Constitución Económica") donde buscan definirse los principios fundamentales que deben normar la organización y el funcionamiento de la actividad económica en la sociedad, así como el papel asignado al Estado y su intervención en este campo. Es así que bajo el Título III de la Constitución y 
más de cincuenta artículos, se consignan disposiciones generales del régimen económico, la regulación de la propiedad, la empresa, los recursos naturales, la actividad agraria, la Hacienda Pública, la moneda y la banca, etc.

Las principales características del régimen económico contenido en la Constitución Peruana de 1979, pueden sintetizarse de la siguiente manera:

1) Señala a la justicia social como su fundamento esencial, orientada a la dignificación del trabajo como fuente principal de riqueza y como medio de realización de la persona humana (art. 110o.).

2) Establece el pluralismo económico (art. 112o.) que supone la coexistencia democrática de distintas formas de propiedad y de organización empresarial (privada, estatal, cooperativa, autogestionaria, comunal, etc.); todas ellas sujetas a un régimen de igualdad jurídica y libre competencia.

3) Se proclama la libertad de iniciativa privada, a desarrollarse dentro de los marcos de una economia social de mercado (art. 115o.) debiendo el Estado estimular y reglamentar su ejercicio para armonizarlo con el in terés social.

4) Se contempla una intervención estatal moderada, que a la par de garantizar el cumplimiento permanente de los principios anotados, puede eventualmente procurar o realizar los objetivos y las acciones siguientes:

- El Estado ejerce la actividad empresarial con el fin de promover la economía del país, prestar servicios públicos y alcanzar el desarrollo (art. 113o.).

- Por causas de interés social o seguridad nacional, la ley puede establecer la reserva para el Estado del desarrollo de determinadas actividades productivas o de servicios (art. 114o.). 
- Ante situaciones de crisis grave o de emergencia, el Estado puede intervenir la actividad económica con medidas transitorias de carácter extraordinario (art. 132o.). Igualmente el Poder Ejecutivo puede dictar medidas extraordinarias en materia económica $v$ financiera, cuando lo requiere el interés nacional y con cargo de dar cuenta al Congreso (art. 211 o. inc. 20).

- Al proscribirse los monopolios, oligopolios y las prácticas de acaparamiento, cabe la intervención estatal para asegurar la normal actividad del mercado (art. 133o.).

- Al reconocer la libertad de comercio e industria, se sujeta a la ley el establecimiento de sus requisitos, garantías, obligaciones y límites; cuidando que su ejercicio no sea contrario al interés social, ni lesivo a la moral, la salud o la seguridad públicas (art. 131o.).

5) La propiedad es concebida como inviolable y nadie puede ser privado de la suya, salvo mediante expropiación por causa de necesidad y utilidad públicas o de interés social declarada conforme a ley y previo pago en dinero de indemnización justipreciada (art. 125o.). La expropiación recibe un tratamiento en exceso restrictivo y anticuado, pues sólo en los casos de guerra, calamidad pública, reforma agraria, remodelación de centros poblados o para aprovechar fuentes de energía; el pago de la indemnización puede efectuarse en efectivo por armadas o mediante bonos, pero siempre debe existir el pago previo de una parte en dinero.

6) La planificación es reconocida, bajo la modalidad de planes de desarrollo de la política económica y social elaborada por el Estado (art. 111 o.), que regulan el desenvolvimien to de la actividad del Sector Público y orientan en forma concertada las actividades de los demás sectores.

7) Un conjunto de funciones de regulación y control de la actividad económica y financiera de entidades estatales y privadas, han sido substraídas de la esfera de dominio del Poder Ejecutivo y encomendadas por la Constitución a órganos autónomos. Son los casos del Banco Central de Reserva, a quien se encarga la regula- 
ción de la moneda y el crédito del sistema financiero, la defensa de la estabilidad monetaria y la administración de las reservas internacionales (art. 149o.); de la Contraloría General, que supervigila la ejecución de los presupuestos del Sector Público, las operaciones de endeudamiento, y la gestión y utilización de bienes y recursos públicos (art. 1460.); así como de la Superintendencia de Banca y Seguros, que ejerce el control de las empresas bancarias, financieras, de seguros y las demás que operan con fondos del público (art. 155o.).

Al analizar estos lineamientos centrales del modelo adoptado por nuestra Constitución en materia económica, Rubio y Bernales (4) concluyen que ". . . plantea un régimen que si bien tiene ambigüedades y contradicciones, es de tendencia liberal con un claro favorecimiento de los intereses del gran capital nacional y extranjero. Las declaraciones de propiciar el acceso de todos a la propiedad de los medios esenciales de vida, quedan como aspiraciones sin referente en las normas concretas (. . .) Las leyes de reforma de 1968-75 han sido en su mayoría morigeradas. Se nota, sí, un intento de modernización del capitalismo y no tanto un regreso (imposible ya) hacia la sociedad oligárquica pre-existente a 1968".

Es sabido que en la asamblea constituyente el Partido Popular Cristiano ejerció gran influencia en la determinación del sistema económico adoptado por la Carta, logrando imponer nociones de corte neoliberal como la economia social de mercado. Este controvertido concepto, fue difundido por la vigente Constitución de Alemania Federal y la Democracia Cristiana germana, siendo recibido como "libertad de empresa en una economía de mercado" por el artículo 380. de la Constitución Española; y luego asimilado ideológicamente en el Perú por los sectores políticos de orientación neoliberal y neocapitalista.

Por ello no se engañan quienes advierten en el eje del régimen

(4) RUBIO, Marcial y BERNALES, Enrique: Constitución s sociedad política; pág. 629. 
económico de nuestra Constitución la presencia significativa de algunos principios de orientación neoliberal, lo que encuentran incongruente e incompatible con la realización del Estado social y democrático de Derecho postulado por la misma Carta al regular el sistema político y los derechos constitucionales. Pero tal afirmación no debe llevar a desconocer aquellas "ambigüedades y contradicciones" del régimen económico que bien advertían Rubio y Bernales, pues la propuesta neoliberal del PPC no quedó plenamente plasmada en la Carta al ser morigerada por las necesarias concesiones que se produjeron en la asamblea constituyente, para arribar a ciertas fórmulas de acuerdo con el APRA y superar las resistencias de la izquierda.

De allí que comparto lo señalado $\mathrm{p} r$ César Ochoa (5) cuando al afirmar el acusado carácter neoliberal del régimen económico de nuestra Constitución, apuntaba que el modelo resultante contenía algunos matices importantes que lo apartan del esquema neoliberal y neocapitalista ortodoxo. Sostiene así que el concepto del Estado subsidiario, elemento esencial del pensamiento neoliberal, queda atemperado y limitado cuando el art. 1120. de la Carta reconoce el principio de la igualdad jurídica entre todos los competidores del mercado, en el marco de un pluralismo económico donde coexisten distintas formas de propiedad y organización empresarial; igualmente cuando el art. 113o. alude directamente al ejercicio de la actividad empresarial por el Estado (5).

Siguiendo este razonamiento manifestaba Ochoa que "... este régimen de paridad al que se someten tanto la empresa privada como la pública, supone una garantía para la iniciativa privada, pues la empresa pública ha de someterse a las reglas de juego del mercado para asegurar su supervivencia. Empero constituye una superación de la concepción ortodoxa, puesto que la actividad

(5) Cfr. OCHOA CARDICH, César: Constitución y economia de mercado; en Derecho No. 39, Revista de la Facultad de Derecho de la Universidad Católica (Dic. 85) pp. 229 a 267; y, Economia y Constitución: la influencia del pensamiento neoliberal en el modelo económico de la Constitución Peruana de 1979; en, La Constitución Peruana de 1979 y sus problemas de aplicación. pp. 613 a 679. 
empresarial del Estado no es consecuencia de un deber de subsidiaridad sino producto de un derecho que le atribuye el reconocimiento de la igualdad jurídica de la iniciativa pública en la actividad económica. Al suprimirse todos los privilegios para cualquiera de las modalidades empresariales, entonces se descarta el principio de subsidiaridad que afirma que la presunción debe jugar siempre en favor de la iniciativa privada y que es sostenido por el neoliberalismo para restringir al máximo la intervención económica del Estado en la actividad empresarial" (6).

Lo dicho ha llevado al citado autor a postular que no cabe una interpretación unívoca y neoliberal ortodoxa del principio de la economía social de mercado plasmado en la Constitución. En cambio, admite como posible y concurrente una interpretación diferente, inspirada en los principios del Estado social y democrático de Derecho recogidos predominantemente en la Cartá. Así "la expresión economía social de mercado no debe leerse (sólo) en sentido restrictivo o neoliberal, sino en el sentido de economía de mercado socializada, que mediante instrumentos "extra-mercado" como la planificación concertada reconocida en el art. 111 o. y el concepto de interés social, permitan una acción reguladora del Estado que oriente al mercado a cumplir fines que no puede conseguir por sí mismo pero que lo dotarán de un horizonte social" (7).

Por su parte, Domingo García Belaunde ( 8 ) ha sugerido también la posibilidad de una interpretación igualmente abierta del modelo, cuando afirma que "la Constitución económica permite diversas lecturas, tanto estrictamente conservadoras, como las que tengan claros matices progresistas. Por cierto que la Constitución no tolera -por lo menos normativamente-- un régimen totalizante,

(6) OCHOA CARDICH, César. Economia y Constitución. . . ;p.671

(7) OCHOA CARDICH, César: Ibid.;pp. 672-673.

(8) GARCIA BELAUNDE, Domingo: La Constitución Económica Peruana; en Revista Peruana de Derecho de la Empresa No. 20 (1986); p. 18. 
absorbente, de feroz estatismo, sea de izquierdas o de derechas; mucho menos un sistema comunista, que significaría además la negación de las clásicas libertades, que todos los constituyentes, sin excepción, se esmeraron en sancionar. Pero sí representa un texto flexible, cuyo alcance, finalidad y propósitos depende no sólo de sus propias normas, sino del entorno social en que se mueva el pais y de las fuerzas políticas actuantes".

Más recientemente, este acertado a nálisis ha sido complementado desde el punto de vista económico por Fernando Sánchez Albavera (9) cuando sostiene que ". . . si bien el Régimen Económico de la Constitución no definió el concepto de Economía Social de Mercado éste puede ser asimilado al de una economía mixta de planificación concertada. Esta determina límites a los derechos de propiedad y a la iniciativa individual pero garantiza el pluralismo empresarial, precisa las funciones del Estado como conductor del proceso de desarrollo y señala la necesidad de armonizar los intereses públicos y no públicos para alcanzar los objetivos nacionales. El Régimen Económico tiene, pues, una naturaleza sustancialmente diferente a lo que se entiende como una economía liberal o privatista, o como una economía estatista, colectivista o de planificación centralizada. Sin embargo, al situarse en un espacio intermedio deja a discreción de quienes tengan en sus manos las riendas de los asuntos públicos a cual de los dos polos se inclinan".

\section{BALANCE DEL DESENVOL VIMIENTO Y EFICACIA DE LOS DERECHOS Y GARANTIAS CONSTITUCIONALES}

“. . La Constitución no es la causa de todos nuestros males ni tampoco la solución de todos nuestros problemas. Su valor debe ser relativizado, pues toda Constitución no sólo tiene cierta dosis de utopía, sino también de ineficacia. Pero indudablemente la Constitución es también algo más. Una Constitución es un

(9) SANCHEZ ALBAVERA, Fernando. "Aplicación y resultados del Régimen Económico de la Constitución"; en, la Constitución diez años despucis (varios autores); "Instituto Constitución y Sociedad" Fundación "Friedrich Naumann" (Lima 1989); p. 83. 
documento político, que expresa aspiraciones, deseos, experiencias y modelos que quieren imponer sus autores. Es un instrumento jurídico, el máximo por excelencia, pero es también un instrumento político. En tal sentido, una Constitución siempre es hija de su época, y conlleva sus aspiraciones y también sus limitaciones. .."

DOMINGO GARCIA BELAUNDE: Cuarenta años de Constitucionalismo Peruano (1936-76). Rev. de Derecho y Ciencius Politicas; No. 41 (1977); p. 105.

La relativa complejidad del modelo global de nuestra Constitución, producto de las concesiones políticas surgidas durante su elaboración, me llevó hace algún tiempo atrás a sostener la hipótesis de trabajo de un "modelo abierto". Este planteamiento sugería que la presencia de un conjunto de principios y enunciados contenidos en la Carta, no siempre compatibles entre sí, podía dar lugar a muy distintas posibilidades de aplicación del tex to constitucional según la composición y orientación política prevaleciente en el régimen de turno, naturalmente dentro de los grandes lineamientos y marcos conceptuales impuestos por la Constitución y su modelo.

Así, los alcances y el funcionamiento de las mismas instituciones constitucionales podrían variar significativamente según el régimen político vigente, condicionando el contenido que por vía legislativa o mediante políticas gubernamentales adquieran muchos derechos enunciados en forma muy general en la Carta, o determinando el mayor o menor grado de utilización de algunos mecanismos de intervención estatal en la economía, así como la intensidad en el uso de las atribuciones legislativas del Poder Ejecutivo o del control político ejercido por el parlamento.

De allí que al evaluar el desarrollo y vigencia de los derechos y garantías constitucionales en estos diez años, debe también apreciarse en que medida las distintas características de los gobiernos de Acción Popular y el APRA pueden haber influido en la orientación que ha correspondido en este período a los derechos y libertades, al sistema político y al régimen económico establecidos en la Constitución. 


\subsection{Los Derechos Humanos, su vigencia y protección}

El tratamiento amplio, progresista e integral que la Constitución Peruana de 1979 brinda a los derechos fundamentales de la persona, ha sido indiscutiblemente el aspecto de la Carta que mayores elogios y entusiasmos ha suscitado dentro y fuera del país. De allí que se haya destacado la ambiciosa y positiva relación de derechos individuales, sociales, económicos, políticos y culturales contenidos en el texto constitucional, propios de una auténtica democracia avanzada.

Pero sería ingenuo creer que la sola inclusión de estos importantes derechos en el texto de la Carta, basta para convertirlos en reales de la noche a la mañana. También sería un error esperar que la aplicación de la Constitución resulte suficiente para tornarnos en una democracia avanzada, superando definitivamente problemas como el autoritarismo, la inestabilidad política, la desigualdad social, la miseria, el subdesarrollo y la carencia de recursos del Estado; situaciones que por tanto tiempo han caracterizado a la sociedad peruana.

De modo que al evaluar los avances y limitaciones en materia de la vigencia y protección de los derechos humanos, en diez años de aplicación de la Carta del 79, debemos tener presente que el desarrollo de toda Constitución está sometido a los condicionamientos de orden político, social y económico de la sociedad en que se desenvuelve. Es así que a los factores estructurales que tornaban bastante lejana la concreción de un régimen de derechos. ciudadanos propio de las democracias avanzadas, se han sumado dos elementos particularmente graves en este período: la aguda crisis económica y la subversión armada, esta última con su secuela de violencia política, represión y estados de emergencia prolongados.

\subsubsection{El relativo avance de los derechos politicos}

Quizás el más importante logro ha sido la continuidad del orden constitucional y de dos gobiernos emanados del sufragio popular. La verificación en estos diez años de dos elecciones presi- 
denciales y parlamentarias (1980 y 85) y de cuatro elecciones municipales a nivel nacional $(1980,83,86$ y 89$)$, viene siendo complementada con la elección y conformación progresiva de los gobiernos regionales, y con las elecciones generales de abril del 90 que permitirán la instauración consecutiva de un tercer gobierno surgido de elecciones democráticas.

Esta realización periódica de procesos electorales, resulta un fenómeno virtualmente nuevo en nuestra accidentada tradición política, lo cual revela un indudable avance en el afianzamiento institucional del derecho de sufragio, elemento esencial para la existencia de la democracia representativa. A ello hay que sumar la democratización pluralista del espectro político, donde las distintas fuerzas y tendencias ideológicas han gozado de legalidad y significativa libertad de acción, salvo quienes se han autoexcluído al optar por la lucha armada.

Otro aspecto positivo del período ha sido la vigencia de una amplia libertad de prensa, producto de la desaparición del control casi monopólico y de la interferencia gubernamental ejercidas sobre los medios de comunicación social durante el régimen militar, así como de la apertura política derivada del surgimiento de nuevos diarios y órganos de prensa vinculados a diversos sectores ideológicos, políticos y económicos. Ello no puede llevar a desconocer que la mayoría de los principales medios de comunicación escrita, de radio y televisión se encuentran claramente vinculados e identificados con los intereses de los grupos económicos dominantes y los sectores políticos conservadores. Asimismo, los medios de comunicación que son propiedad del Estado continúan utilizándose como canales de propaganda al servicio del partido gobernante, sin permitirles acceso a los diversos sectores politicos y sociales del país, pese a que ello es postulado por la Constitución.

En el período también se han hecho evidentes las limitaciones de este modelo restringido e insuficiente de democracia representativa, que resulta en exceso formal por basarse exclusivamente en el ejercicio periódico del sufragio para elegir gobernantes y representantes. Pero desprovisto de mecanismos de participación 
popular en la toma de decisiones políticas gubernamentales y de canales institucionales a través de los cuales se expresen y reciban las demandas de las organizaciones populares.

Durante los últimos años han surgido numerosas experiencias de organización popular autónoma, tales como los clubes de madres (comités del vaso de leche, comedores populares) comités barriales, rondas campesinas, etc. Se trata de instancias asociativas mediante las que los sectores sociales más pobres han procurado afrontar sus necesidades en materia de alimentación, habilitación urbana, obtención de servicios, trabajo y seguridad; frente a la desatención de las políticas y autoridades estatales, los estragos de la crisis económica y la violencia. Sin duda que estas organizaciones - a menudo ignoradas, combatidas o víctimas de los intentos de manipulación gubernamental o partidaria - son expresión auténtica de una convicción popular democrática y solidaria, que busca ensanchar los estrechos límites de la participación exclusivamente electoral.

Dentro de la imprescindible y aún pendiente tarea de democratizar el Estado e impulsar la participación popular en el proceso de toma de decisiones políticas gubernativas, estas organizaciones constituyen un componente indispensable para superar las limitaciones del modelo representativo vigente.

\subsubsection{La vida, la libertad e integridad personal, los derechos más vulnerados}

La violencia desatada por la acción terrorista y la lucha armada subversiva, así como la respuesta represiva del Estado, nos han arrastrado a una situación inédita de violencia y muerte. El derecho a la vida viene siendo vulnerado tanto por la acción cruel y equivocada de quienes absurdamente matan y destruyen creyendo que así mejorarán nuestro país, como también por los no pocos excesos represivos de las fuerzas del orden, la mayoría de los cuales permanecen sin sanción ni voluntad de enmienda.

En estos diez años de régimen constitucional, la acción subversiva y la respuesta represiva han producido más de 15 mil 
muertos. Entre 1980 y 1988, según diversos estudios, las víctimas de la violencia política fueron aproximadamente 12 mil, conforme se aprecia en el cuadro comparativo siguiente (10):

\section{CUADRO COMPARATIVO SOBRE LAS VICTIMAS DE LA VIOLENCIA POLITICA POR SECTOR (1980-88) SEGUN EL MINISTERIO DE DEFENSA, LA COMISION ESPECIAL DEL SENADO SOBRE VIOLENCIA Y PACIFICACION Y DESCO}

Sector

FF.PP.

FF.AA.

Civiles

Subversivos

TOTAL
M. de Defensa (*) 426

138

4,179

4,489

9,232
Com. del Senado

849 (**) $^{* *}$

**

4,936

6,828

12,613
DESCO

566

292

5,161

5.292

11,311

FUENTE: Violencia politica en el Perú 1980-1988. DESCO (1989); Tomo I, pág. 44.

Lo más alarmante es que sólo en el año 1989 se produjeron 3,198 nuevas víctimas, lo que elevó el saldo de muertos a casi 16 mil y convirtió a este último año en el más violento de la década. Según el informe sobre el año 1989 recientemente publicado por la Comisión Especial del Senado (11), que preside el senador Enrique Bernales, de estos 3,198 muertos 348 correspondieron a

(10) Cfr. DESCO: Violencia politica en el Perú 1980-1988. 1989; 2 tomos, 1,080 págs. Y Comisión Especial del Senado sobre causas de la violencia y alternativas de pacificación en el Perú; Violencia y Pacificación, informe publicado por DESCO y la CAJ (1989); 416 pags.

(*) Las cifras del M. de Defensa son hasta el 22 de junio de 1988.

(**) La Comisión del Senado utiliza la clasificación "fuerzas del orden", que involucra a las víctimas de las FF.PP. y FF.AA.

(11) La violencia en el Peri: Informe 1989 de la Comision Isp. del Senado sobre las causas de la violencia y alternativas de pacificación en el Perí. (Feb. de 1990); p. 15. 
miembros de las fuerzas del orden, 1,450 eran civiles, 1,251 presuntos subversivos y 149 producto del narcotráfico. Todo ello ha llevado a que en 1989 mueran un promedio de 9 personas cada día por efecto de la violencia política. Pero sucede que esta elevada cifra puede ser aún mayor, por efecto de los numerosos casos denunciados de detenciones-desapariciones y de ejecuciones extrajudiciales a manos de las fuerzas de seguridad (donde los cadáveres han sido ocultados), asi como de muertes no reportadas ocasionadas en la población civil por acción subversiva en lugares muy apartados, o de bajas no precisadas sufridas por los grupos subversivos en enfrentamientos con las fuerzas del orden.

La situación tampoco ha resultado nada alentadora en el caso del derecho a la libertad e integridad personal. De acuerdo al art. 2o. inciso 20-g) de la Constitución, las personas sólo pueden ser detenidas por la policía en cumplimiento de una orden judicial o en caso de ser capturadas en flagrante delito, debiendo ser puestas a disposición del juez dentro de las 24 horas de producida la detención. Sin embargo, pese a esta restricción constitucional, las autoridades policiales han proseguido recurriendo con exagerada frecuencia a efectuar detenciones por causas distintas a las previstas en la Constitución, tales como el arresto de presuntos sospechosos o con fines investigatorios, la detención de personas indocumentadas, la realización de "redadas", etc.

Es de lamentar que las autoridades judiciales, al conocer de casos donde se han cuestionado estas detenciones arbitrarias, hayan optado mayoritariamente por el inconveniente criterio de admitir como válida cualquier detención policial - sin interesarse por evaluar la causa que la motiva - a condición de que ésta no exceda de 24 horas. Este comportamiento, sin duda impropio del papel protectivo de los derechos de la persona y de la Constitución que debe corresponder a la judicatura, ha contribuido a la continuidad de esta inadecuada conducta policial, así como a convalidar detenciones carentes de la necesaria racionalidad que debe exigirse para justificar la privación de la libertad.

La vigencia prolongada del estado de emergencia en diversas zonas del país, ha favorecido estas conductas antidemocráticas, 
colocando a la población - especialmente a los más pobres-en una situación constante de amenaza a su libertad e integridad personal. Los excesos en materia de detenciones se han hecho así muy frecuentes y la pasividad judicial más notoria.

\subsubsection{La ausencia de desarrollo de los derechos económicos y sociales}

Si bien se puede decir que la profunda crisis económica que viene sufriendo el país, derivada en gran parte de las desacertadas políticas impulsadas por los dos gobiernos de esta década, ha impedido al Estado destinar recursos importantes para atender servicios esenciales de la población, lo cierto es que no ha existido una voluntad política resuelta a adoptar medidas que permitan avances significativos en la satisfacción de los derechos económicos y sociales contemplados en la Carta. Incluso puede afirmarse que si muchos de esos derechos aparecían como meras aspiraciones bastante alejadas de la realidad cuando entró en vigencia la Constitución, al cabo de estos años dicha distancia se ha acrecentado, como se constata fácilmente al verificar el dramático deterioro en los niveles de alimentación, acceso a la salud y vivienda. empleo y remuneraciones, que afrontan la mayoría de peruanos.

Muchos de los derechos reconocidos en la Constitución cuyo desarrollo y precisión habían quedado supeditados al dictado de leyes regulatorias (especialmente en el campo laboral) permanecen todavía pendientes de normación por la morosidad o el desinterés de los gobiernos y sus mayorías parlamentarias. "Más desalentador aún resulta constatar que las normas de tipo programático previstas en la Carta, en aspectos fundamentales como la promoción del empleo, la salud, la vivienda, la alimentación o las remuneraciones: no sólo han sido ignoradas por las políticas gubernamentales, sino que muchas veces han resultado notoriamente vulneradas por decisiones de efecto regresivo en estos campos. .

La efectiva vigencia de la propiedad en nuestro país. por ejemplo, implica realizar transformaciones que democraticen el acceso de este derecho para todos los ciudadanos. antes que restringirlo a la defensa de los privilegios patrimoniales de que disfru- 
tan unos pocos. En tal sentido resultan positivos los procesos de reconocimiento legal de asentamientos humanos populares y el otorgamiento de títulos de propiedad sobre las viviendas que ocupan los pobladores, acciones desplegadas principalmente en la gestión municipal de Izquierda Unida y el APRA.

Pero se trata de actos que conllevan "legalizar" situaciones de hecho pre existentes. Y ello, aunque importante, resulta insuficiente si se deja de lado la aplicación de modificaciones a nivel de la sociedad en el sistema de propiedad, la organización de la actividad productiva, $y$ en la vocación y estructura del Estado; medidas que deben permitir a las mayorías nacionales la mejor satisfacción de los derechos económicos y sociales plasmados en la Carta, los que hasta la fecha permanecen tan sólo como una promesa, a ratos cada vez más lejana de cumplirse.

\subsubsection{La vigencia y eficacia de las garantias constitucionales}

a) Habeus Cormus. Si algo caracterizó al Habeas Corpus en el Perú, fue su escasa utilización y virtual ineficacia, en gran medida debido a la existencia prolongada de gobiernos de facto y regímenes de excepción, que suspendieron la vigencia de las garantías constitucionales, asi como a la significativa sumisión del aparato judicial frente a quienes detentaban el poder político.

Es así que Domingo García Belaunde, luego de rigurosos estudios para identificar y analizar las resoluciones dictadas y publjcadas en el país en materia de Habeas Corpus, señala que entre 1933 (fecha de entrada en vigencia de la anterior Constitución) y 1970 se produjeron 182 de estas acciones, principalmente en defensa de la libertad individual y el derecho de propiedad, y en segundo orden por la libertad de trabajo y recursos interpuestos contra los municipios. Asimismo, para un período más amplio. comprendido entre 1898 (desde la aplicación de la primera ley de Habeas Corpus dictada en 1897) y 1973, consigna un total de 264 resoluciones, que son aquellas de cuya existencia se tiene evidencia (12).

(12) Cfr. GARCIA BELAUNDE, Domingo: th habeas corpus interpretado. 
La primera conclusión que cabe hacer de la aplicación del Habcas Corpus en estos diez años de régimen constitucional, en especial desde la vigencia de la Ley 23506 de diciembre del 82, es que su utilización se ha acrecentado grandemente en comparación con el período anterior, sin duda debido a la continuidad democrática, al avance en la institucionalidad constitucional y a la mayor difusión de esta acción. En efecto, de acuerdo a la investigación que hemos realizado (13), entre enero del 83 y diciembre del 87 se resolvieron y publicaron en el diario oficial 1.039 acciones de Habeas Corpus. Sin embargo asistimos desde 1986 a un pronunciado y continuo decrecimiento en el número de acciones interpuestas, lo que podría explicarse en parte por la vigencia prolongada desde entonces del estado de emergencia en diversas zonas del país. Pero pensamos que principalmente responde al desencanto de la ciudadanía ante el escaso éxito judicial que han alcanzado las acciones, pues puede notarse (en el siguiente cuadro) que mientras en 1983 fueron declaradas "fundadas" el 24.3\% de las acciones, este porcentaje ha cafdo fuerte e ininterrumpidamente hasta llegar al insignificante $3.6 \%$ en 1987.

\section{ACCIONES DE HABEAS CORPUS RESUELTAS Y PUBLICADAS} (1-1-83 al 31-12-87)

$\begin{array}{lccr}\text { Año } & \text { No. de Acciones } & \text { Resoluc. "Fundadas" } & \text { Porcentaje } \\ 1983 & 111 & 27 & 24.3 \% \\ 1984 & 287 & 27 & 9.4 \% \\ 1985 & 288 & 22 & 7.6 \% \\ 1986 & 244 & 12 & 4.9 \% \\ 1987 & 109 & 4 & 3.6 \% \\ \text { TOTAL } & \mathbf{1 , 0 3 9} & \mathbf{9 2} & \mathbf{8 . 8 \%}\end{array}$

IVUENTE: Resoluciones publicadas en el diario "El Peruano".

PUC (1971); 445 pags. Y Fl habeas corpus en el Peru. UNMSM (1979); 235 pags.

(13) Investigación Libertad individual e integridad personal en los ambitos policial, judicial y familiar: elaborada por FRANCISCO EGUIGUREN, 
Del total de las acciones de Habeas Corpus, la gran mayoría de éstas fueron interpuestas para cuestionar supuestas detenciones arbitrarias (casi el 70\%), pudiendo apreciarse que sobre 721 causas que alegaron dicha violación de la libertad personal, en el año 83 se declararon "fundadas" 20 acciones, en el 84 fueron 17 , en el 85 prosperaron 16 , en el 86 fueron 8 y en el 87 sólo 2 acciones; lo que determina un promedio global del $8.7 \%$ de resoluciones judiciales que finalmente declararon "fundada" la acción interpuesta, aunque no debe dejar de advertirse que el porcentaje de éxito ha decrecido drásticamente cada año.

No puede descartarse que muchas acciones hayan sido interpuestas sin fundamento o que el derecho haya sido restablecido en el curso del proceso. Sin embargo, nuestra investigación ha constatado que muchas de las resoluciones judiciales que declararon improcedentes las acciones dejaron de efectuar el necesario control o examen del fundamento causal o racional de la detención, limitándose a evaluar el plazo de duración de la misma o a admitir pasivamente la manifestación policial. Es así que muchas detenciones arbitrarias han quedado convalidadas por la poca sensibilidad judicial evidenciada en la protección de la libertad personal tan frecuentemente vulnerada.

Finalmente, cabe tener presente que el número de acciones de Habeas Corpus interpuestas es ostensiblemente bajo, si se le compara con la elevada cifra de detenciones arbitrarias que se producen cotidianamente. las cuales tienen este carácter por no ajustarse ...en rigor a las causales previstas en la Constitución o por carecer de un fundamento razonable que las justifique. Ello implicaría que, por lo general, los casos de detención encuentran una solución extra-judicial, pues la persona recobra su libertad por acción de la propia policía, ya sea luego de efectuar ésta una sumaria calificación e investigación. o debido a gestiones de los familiares del detenido que logran el apoyo de personas influyentes o de autoridades; en otros casos, la libertad es dispuesta por el Minis-

WALTER ALBAN y SAMULL ABAD. APEP Informe final (enero 89); 420 pags. 
terio Público, al constatar que el hecho alegado no constituye delito o se carece de evidencias suficientes para la detención. No deben descartarse, además, casos frecuentes de corrupción o extorsión, donde la libertad (sea en la etapa policial o judicial) se consigue a cambio del pago de dinero, ya sea por ofrecimiento del interesado o ante la demanda de algunas autoridades o funcionarios.

Pareciera que la interposición del Habeas Corpus (normalmente a sugerencia del abogado) sólo se intenta cuando, por la naturaleza del caso o de la persona detenida, se tiene escasa confianza en el éxito de las gestiones informales para obtener la libertad; o después de haber realizado éstas sin resultado favorable. El Habeas corpus sería así una suerte de último recurso, al que mayormente sólo se acude a falta o ante el fracaso de otras soluciones que se perciben como más eficaces, pues el escaso porcentaje de posibilidades de éxito judicial que alcanzan estas acciones - más aún durante la vigencia del estado de emergencia- no incentiva su utilización en la medida que la realidad lo haría exigible.

b) Amparo. En cuanto a la acción de amparo, considero que su desenvolvimiento ha seguido un proceso distinto al Habeas Corpus, pudiendo distinguirse dos grandes etapas en la jurisprudencia surgida de esta acción y en su eficacia. La primera abarca el período comprendido desde el inicio de la vigencia de la ley 23506 (diciembre de 1982) hasta mediados del 87; la segunda puede decirse que comienza con el intento del gobierno aprista de estatizar el sistema bancario y financiero, en el segundo semestre del 87 , continuando hasta la actualidad aunque con la importante modificación producida en el amparo con la ley 25011 de febrero del 89.

En el primer período, de acuerdo a una investigación realizada por Marcial Rubio, Francisco Eguiguren y Samuel Abad (14),

(14) RUBIO, Marcial, EGUIGUREN, Francisco y ABAD, Samuel: Evaluación de cuatro años de hábeas corpus y amparo en el Perú: 1983-1986; estudio (pendiente de publicación) realizado por los autores como ampliación y desarrollo de un informe anterior elaborado en 1986 para APEP, sobre el periodo $1983-85$. 
entre enero de 1983 y diciembre del 86 se resolvieron 1,832 acciones de amparo (publicadas en el diario oficial "El Peruano") de las cuales una gran mayoría, por lo menos el $60 \%$ de ellas, fueron interpuestas contra sentencias dictadas en procesos judiciales. lo que por lo general conlleva trasladar al amparo procedimientos seguidos previamente entre particulares ante sede judicial, con la intención de lograr en esta vía una decisión que permita subsanar algún vicio cometido en el juicio, dictar un nuevo fallo o impedir el cumplimiento de la resolución cuestionada.

El derecho de propiedad se ubica en segundo orden de importancia cuantitativa, pues fue expresamente invocado en 86 acciones (4.7\%); en tercer lugar cabría hablar de derechos de tipo laboral, que en conjunto suman unos 115 casos, la mayoría de ellos referidos a beneficios sociales, derecho al trabajo y estabilidad en el empleo, apareciendo en menor medida casos de sindicalización, huelga o negociación colectiva.

Dicha investigación, además, permite apreciar otros dos aspectos muy importantes:

- En 1.105 de los casos, es decir el $60 \%$ de las 1.832 acciones analizadas, la resolución (publicada) que pone fin al proceso ni siquiera permite determinar cuál fue el derecho invocado en la causa $\mathrm{y}$, normalmente, tampoco los fundamentos jurídicos que sustentan al fallo. Con esta lamentable práctica judicial, por lo general apreciada en las sentencias que dictan los órganos de mayor jerarquía, se incumple el propósito esencial que se perseguía cuando la ley 23506 dispuso la publicación obligatoria de estas sentencias, que no era otro que difundir los criterios de interpretación y motivación adoptados por los tribunales (que debían servir como precedentes) acerca de los alcances de los derechos constitucionales, asignando a la jurisprudencia un rol esclarecedor y pedagógico. Puede concluirse, sin embargo, que muchos de estos casos donde el derecho o la pretensión no aparecen determinados en la sentencia, corresponden a acciones de amparo contra resoluciones judiciales, por ser jueces y magistrados a quienes se sindica como demandados. 
- Los niveles de éxito judicial alcanzados en las acciones de amparo fueron desde un principio muy bajos y se mantuvieron sin mayor alteración porcentual en el período, a diferencia del Habeas Corpus donde incluso se observa una marcada tendencia decrecienic en el número de causas resueltas en favor del accionante. En il amparo, de las 1,832 acciones de los cuatro años, sólo 123 (es decir el 6.7\%) fueron declaradas "fundadas"; si a ello sumamos 36 casos donde el TGC casó resoluciones denegatorias del amparo dictadas por la Corte Suprema, el promedio de éxito judicial logralo en estas acciones se eleva tan sólo al 8.6\%. La eficacia del amparo fue entonces realmente escasa, sin que deba descartarse que de esta inmensa mayoria de sentencias que consideraron carente de fundamento la acción promovida, buena parte de ellas hayan sido adecuadamente resueltas por las graves distorsiones y maniobras que desde un principio caracterizaron a la actuación de muchos demandantes y a sus pretensiones.

Con respecto a las acciones interpuestas contra resoluciones judiciales, que predominaron ampliamente en este primer período, Samuel Abad (15) señala que sobre un total de 1,679 resoluciones de amparo publicadas en "El Peruano" entre el 24-12-82 y el 31-12-86, nada menos que 1,025 (el 61\%) fueron interpuestas contra sentencias. Un $33 \%$ de estos casos se promovieron para impedir la ejecución de la orden de desalojo en cumplimiento de fallos recaíclos en juicios de desahucio y aviso de despedida, lo que normalmente denotaría un propósito dilatorio dolosamente premeditado del demandante afectado por dicha resolución. Parte importante de los otros casos alegaron irregularidades o vicios procesales en la tramitación de juicios de diversa naturaleza.

(abe mencionar, sin embargo, que de estas 1,025 acciones $\mathrm{de}$ amparo contra resoluciones judiciales, sólo 4 de ellas (el $0.39 \%)$

(15) Cfr. ABAD YUPANQUI, Samuel: ¿Procede el amparo contra resoluciones judiciules?; y la acción de amparo contra resoluciones judiciales. Un estudio cuantitativo de jurisprudencia constitucional. En Lecturas sobre temas constitucionales, Nos. 2 y 3; Comisión Andina de Juristas (Dic. 88 y Agto. 89). 
fueron declaradas "fundadas". Lo que permite afirmar que estas acciones carecieron casi totalmente de eficacia y que la jurisprudencia (en algunos casos tal vez extremadamente restrictiva) intentó desalentar los notorios abusos y maniobras dilatorias que muchas veces se buscaron instrumentar con este tipo de acciones. Sin embargo, pese a esta falta de éxito judicial en la pretensión, se prosiguieron formulando gran número de estas demandas, lo que sin duda evidenciaría la actuación poco escrupulosa de muchos abogados y litigantes.

El segundo período en la evolución del funcionamiento del amparo aún no ha sido suficiente y sistemáticamente estudiadó, por lo que resultaría apresurado afirmar con certeza que las tendencias de la etapa anterior, en cuanto al tipo de acción predominante y el sentido de los fallos, hayan sido total o parcialmente modificadas en sus aspectos centrales. Existen, sin embargo, algunas situaciones nuevas que me inducen a considerar la presencia de una etapa distinta, donde los rasgos predominantes en el desenvolvimiento del amparo son otros. $\mathrm{Y}$ éstos son la politización del amparo, su conversión en un instrumento para la defensa de intereses económicos y patrimoniales grupales o gremiales, antes que de auténticos derechos en sentido estricto; el traslado a esta vía judicial de la oposición política a decisiones y medidas gubernamentales, principalmente por parte de sectores empresariales privados pero también de acciones reivindicativas de los trabajadores; sin descartar conflictos laborales, sobre condiciones de trabajo, negociación colectiva e indexación de remuneraciones, que han enfrentado conjuntamente a organizaciones patronales, sindicatos $\mathrm{y}$ entidades gubernamentales.

Quizás el hecho que marcó el inicio de este nuevo período. fue el controvertido y frustrado intento gubernamental de estatizar el sistema bancario y financiero, a nunciado sorpresivamente el 28 de julio de 1987 y puesto en marcha en los meses siguientes, en medio de serios enfrentamientos con los sectores empresariales privados afectados y de profundas contradicciones al interior del gobierno que se tradujeron en políticas erráticas y medidas incoherentes. Todo ello dio origen a un intrincado debate judicial a través de numerosas acciones de amparo, asi como al deterioro que 
empezó a sufrir la actividad económica nacional, a consecuencia de la pérdida de confianza y el conflicto que desde entonces caracterizaron las relaciones entre gobierno y gremios empresariales privados.

Este enfrentamiento político y judicial del gobierno aprista con los empresarios privados, se extendió a otros sectores de la actividad económica donde surgieron nuevos conflictos. Recuérdese, entre otros, los amparos de los armadores y empresarios pesqueros, en oposición a la renovación y ejecución de un convenio del gobierno con la flota pesquera soviética; los amparos nacidos entre el gremio de los empresarios mineros y el régimen, a raíz del intento de establecer la negociación colectiva articulada con la federación de trabajadores del sector; o los amparos promovidos por grupos empresariales para dejar de cumplir convenios colectivos o resoluciones administrativas de indexación salarial a la par de la inflación; o el reciente anuncio de próximos amparos de CAPECO para impedir la aplicación de la ley que crea la "Bolsa de Trabajo", a ser administrada por los sindicatos de trabajadores de la construcción civil.

Pero así como estos conflictos aislaron definitivamente al gobierno del sector empresarial, muchas decisiones de índ ole laboral y económica iniciaron y agudizaron también sucesivos enfrentamientos con las organizaciones de los trabajadores. Recuérdese el amparo contra la medida del gobierno que modificó la jornada y el horario de trabajo durante el verano, interpuesto con éxito por la Federación de Empleados Bancarios; o las acciones promovidas por los servidores públicos demandando el cumplimiento de la homologación de sus remuneraciones; o los amparos de trabajadores de empresas de propiedad del Estado, reclamando el cumplimiento de convenios colectivos que disponen el reajuste periódico de las remuneraciones según los índices de inflación.

La instrumentalización del amparo en función de intereses políticos y conflictos de incidencia económica y social, que ha sido el rasgo predominante de este período, tuvo algunas implicancias decisivas en el desenvolvimiento y alcances de esta acción: 
- De un lado, se produjeron serias distorsiones que llevaron a desnaturalizar el amparo, al punto de convertirlo en un escenario al que se trasladaban deliberadamente cuestiones que debían ventilarse a través de otro tipo de procesos judiciales, o que constituían cuestiones políticas no justiciables. Pero además, la actuación poco escrupulosa de algunos jueces y abogados, sea por ignorancia jurídica o por la sumisión económica a los intereses de alguna de las partes, llevó a que se interpusieran, admitieran y hasta resolvieran en forma favorable acciones de amparo que, a la luz de un análisis serio de dicha institución, debieron ser rechazadias.

Me refiero a casos tan insólitos como el de resoluciones judiciales que consideraron viable el amparo contra un proyecto de ley que se debatía en el Congreso (el de estatización de la banca) pretendiendo ordenar al parlamento que se abstuviera de aprobar dicha ley y al Presidente y funcionarios administrativos que no lo promulgaran o ejecutaran, respectivamente; o cuando sectores empresariales intentaron (en muchos casos con éxito) amparos directos contra leyes que no tenían carácter autoaplicativo. Y no hace mucho, la organización que agrupa a los trabajadores estatales anunció la interposición de un amparo contra un candidato a la Presidencia de la República, debido a que éste anunció en su campaña que de llegar al poder reduciría el aparato estatal y el número de los servidores públicos, lo que calificaban como una "amenaza" a su derecho a la estabilidad laboral por el riesgo de ser despedidos.

El factor que más propició esta exagerada interposición de amparos, fue la concesión (a menudo irracional y apresurada por algunos malos jueces) de la medida cautelar de suspensión provisional del acto reclamado, en base al simple pedido (rara vez bien fundamentado o justificado) del propio demandante que era quien escogía al juez a que se presentaba la acción. Todo ello, y no sin razón, hizo mucho daño a la percepción social del amparo, pues se generaron explicables suspicacias acerca de la conducta de ciertos abogados y jueces comprometidos en prácticas dolosas e inmorales, motivadas por la búsqueda de beneficios económicos. Fue así que se dictaron medidas cautelares antojadizas y sin fundamento jurídico, que suspendían la aplicación de una ley, un 
convenio internacional o un convenio colectivo de trabajo, pese a estar plenamente vigentes y gozar - cuando menos- de una presunción inicial de validez y constitucionalidad; o de situaciones absurdas y caóticas debido a medidas cautelares dictadas en un proceso de amparo, para disponer la inejecución di otra medida de suspensión provisional (de sentido opuesto) dispuesta en otro amparo entre las mismas partes.

- De otro lado, la instrumentalización del amparo llevó a que se interpusieran muchas acciones donde no interesaba llegar al fallo final, ya sea porque se sabía de antemano que el resultado difícilmente sería favorable, ante el escaso sustento de la pretensión, o debido a que el amparo se iniciaba para obtener una medida cautelar (a veces previamente concertada) y utilizarla como un meca nismo publicitario para pretender "legitimar" (mediante campañas en los medios de comunicación) sus exigencias y negociar políticamente en mejores términos con el Gobierno. Ello explica, por ejemplo, el notorio éxito logrado por esta vía con los amparos promovidos contra la estatización de la banca y los procesos expropiatarios, que sin duda forzaron al Gobierno a abandonar su trasnochado e incoherente intento, pese a que dichas acciones (desde el punto de vista procesal) fueron luego virtualmente paralizadas y siguen pendientes de resolución en las instancias superiores del Poder Judicial.

No debe pensarse, por lo dicho, que desconozca la importancia del amparo y de muchos resultados positivos conseguidos en la protección de los derechos constitucionales. Sucede simplemente que el saldo final de este balance del desenvolvimiento del amparo mostraba un serio deterioro en su credibilidad, así como una peligrosa tendencia al predominio de resoluciones caren tes de suficiente sustento y solidez desde el punto de vista del Derecho, que sólo creaban inseguridad y caos en las relaciones juridicas y parálisis en el funcionamiento de la Administración Pública.

De allí que no sorprendió demasiado la aprobación por el Congreso ( $\sin$ mayores dificultades ni resistencias) de la ley 25011 de febrero del 89, que modificó algunos aspectos importantes del amparo. Dicha ley -inevitable ante los excesos y distorsiones co- 
mentadas, así como frente a la incapacidad del Poder Judicial para autorregularse y corregir estas prácticas- delimitó en función de un turno especial la determinación del juez competente para conocer del amparo, evitando su inconveniente y sospechosa selección por el propio demandante; ello resulta positivo, aunque una solución de este tipo, adoptada en forma anterior y oportuna, pudo haber evitado que se produjeran las lamentables distorsiones ya señaladas.

Sin embargo, la reforma establecida en cuanto a la medida cautelar de suspensión del acto reclamado la encontramos exagerada e inconveniente, pues desnaturaliza y puede tornar ineficaz dicha institución fundan ental, al hacer muy rígida y dilatada su concesión con grave riesgo para un derecho efectivamente afectado, que puede sufrir un daño irreparable. Desde un principio me he manifestado profundamente contrario a esta modificación (16) pues si bien el remedio aparecía como necesario e inevitable, la fórmula de solución adoptada presenta tales características y riesgos que tienden a convertirla en peor que el mal que se pretendía combatir.

Pareciera que con esta reforma se han controlado muchos de los excesos cometidos en el uso del amparo, pero también se ha atentado seriamente contra sus alcances y eficacia. El tiempo debe permitir evaluar los resultados y efectos de esta modificación, pero insistimos en la convicción de una indispensable recuperación de la plena eficacia (hoy escasa o inexistente) de la medida cautelar de suspensión provisional del acto reclamado, lo cual sin duda se verá facilitado cuando se imponga una utilización racional y responsable de la acción de amparo, y cuando los jueces asuman el insustituible papel que les corresponde para alcanzar este objetivo.

(16) Cfr. EGUIGUREN, Francisco: La ley 15011 de reforma a la acción de amparo: razones para una discrepancia; en Lecturas sobre temas constitucionales 3; Comisión Andina de Juristas (agosto de 1989). En esta revista aparecen también los muy importantes e interesantes trabajos de los profesores Domingo García Belaunde, Juan Monroy y Aníbal Quiroga; quienes evalúan la reforma introducida mediante la ley 25011 y manifiestan su posición frente a ella. 
c) El Tribunal de Garantias Constitucionales. La creación del TGC fue una de las interesantes novedades de la Carta del 79, buscando que con este órgano especializado se encontrara remedio a la tradicional inoperancia que había evidenciado el Poder Judicial para ejercer el control de la constitucionalidad de las leyes y los actos gubernamentales. Este tribunal, con sede en Arequipa (por decisión de la Constitución), se instaló en noviembre de 1982.

Existe relativo consenso en considerar que el TGC no ha logrado alcanzar la gravitación y trascendencia en la vida nacional que se pretendió con su incorporación constitucional; incluso se tiende a percibir su rol como cada vez más deslucido o diluido. Entiendo que tales impresiones son esencialmente correctas, pero la adecuada evaluación del papel que ha desempeñado este órgano, exige tener muy presente algunos factores derivados del propio diseño que le atribuyó la Constitución, los cuales también han incidido en su actuación poco relevante: (17)

- El modelo previsto en la Constitución para el TGC, le ha conferido una competencia y capacidad de acción muy limitadas $y$ restringidas. Es así que sólo puede conocer, en forma residual, de las acciones de Habeas Corpus y amparo que previamente hayan sido denegadas por la Corte Suprema, y siempre que el persistente litigante decida seguir luchando e interponer el recurso de casación pertinente, luego de transitar por tres instancias del Poder Judicial y de haber fracasado. Asimismo puede conocer directamente de las acciones de inconstitucionalidad contra leyes, decretos legisla tivos, normas regionales de carácter general y ordenanzas municipales; pero éstas sólo pueden ser promovidas por el Presidente de la República, 20 senadores, 60 diputados, el Fiscal de la Nación, la Corte Suprema o 50 mil ciudadanos. De modo que el

(17) Cfr. El Tribunal de Garantias Constitucionales en debate, varios autores; "Enfoques peruanos 6", editado por la Comisión Andina de Juristas, el Consejo Latinoamericano de Derecho y Desarrollo y la Fundación Friedrich Neumann: (Dic. 86) 163 pags. En este trabajo se recogen los planteamientos de diversos especialistas expuestos en un fórum de agosto del 86 , destinado a evaluar el funcionamiento del TGC. 
TGC sufre las consecuencias de un diseño que le impone demasiados condicionamientos, pues sólo un número muy limitado de acciones pueden llegar a su conocimiento y siempre sujetas a la iniciativa de quien decida emprender dicha causa.

- La experiencia y el tiempo transcurridos revelan que ha resultado contraproducente la decisión del constituyente de establecer la sede del TGC en Arequipa, pues ello ha acrecentado las dificultades de acceso al tribunal y terminado por desalentar - debido a razones materiales y económicas- el recurrir ante este órgano. Ello no sólo porque la gran mayoría de acciones de Habeas Corpus y amparo se originan en Lima, sino sobre todo por lo dilitado y árduo que este trámite resulta para los casos surgidos en provincias, que previamente han tenido que trasladarse a la capital para comparecer ante la Corte Suprema, y luego deben verificar un nuevo desplazamiento hacia Arequipa, para continuar la batalla judicial ante el TGC.

- Estos factores han determinado que el número de acciones de Habeas Corpus y amparo sometidas al conocimiento del TGC haya sido relativamente escaso, sobre todo si se lo compara con lia cantidad de causas que fueron denegadas por la Corte Suprema. En el cuadro siguiente podemos apreciar los casos que llegaron al TGC en sus cinco primeros años de funcionamiento.

\section{ACCIONES DE HABEAS CORPUS Y AMPARO ANTE EL TGC}

$$
\text { (1-12-82 al 31-12-87) }
$$

$\begin{array}{ccccccc}\text { ACCION } & \mathbf{1 9 8 3} & \mathbf{1 9 8 4} & \mathbf{1 9 8 5} & \mathbf{1 9 8 6} & \mathbf{1 9 8 7} & \text { TOTAL } \\ \text { - Habeas Corpus } & 03 & 14 & 05 & 13 & 13 & 48 \\ \text { - Amparo } & 27 & 54 & 27 & 51 & 66 & 225 \\ \quad \text { TOTAL } & \mathbf{3 0} & \mathbf{6 8} & \mathbf{3 2} & \mathbf{6 4} & \mathbf{7 9} & \mathbf{2 7 3} .\end{array}$

Fuente: Resoluciones del TGC publicadas en "El Peruano".

Al ser reducido el volumen de causas de Habeas Corpus y amparo que llegaron al TGC, tanto por razones del diseño constitucional como por factores de orden material, sus posibilidades de 
conocer casos relevantes y de emitir resoluciones de trascendencia jurídica y politica se han visto seriamente limitadas.

En el fondo, el interés de la cuestión cuantitativa pareciera circunscribirse a saber en cuantas acciones el TGC casó las resoluciones expedidas por la Corte Suprema y en cuantos otros compartió un criterio similar. Es así que en materia de Habeas Corpus, sobre un total de 48 casos en cinco años, sólo en 3 casos se resolvió por la casación, en 38 no se concedió y en 7 causas el tribunal no pudo expedir sentencia. En las acciones de amparo, entre 1983 y 1986 se conocieron 157 casos, resolviendo en favor de la casación 36 de ellos, declarándola sin lugar en 103 casos y en 18 causas no se pudo expedir sentencia. De modo que en materia de Habeas Corpus, el TGC compartió casi siempre el criterio de la resolución de la Corte Suprema, pues sólo el $6.25 \%$ de casos merecieron la casación; en cambio, tratándose de las acciones de amparo el margen de discrepancia fue mayor, pues se resolvió en favor de la casación el $22.92 \%$ de casos, cifra que - sin embargo- tampoco llega a ser demasiado significativa.

Desde el punto de vista del aporte cualitativo de la jurisprudencia del TGC, existieron algunos casos de amparo donde se dictaron resoluciones que han contribuido a esclarecer conceptos juridicos importantes como cuando existe una amenaza de un derecho, qué debe entenderse por una via paralela, cuando no resulta exigible el agotamiento de la vía previa, o que situaciones configuran un proceso judicial irregular que vulnera el derecho al debido proceso. Adicionalmente se dieron unos pocos casos de amparo que alcanzaron alguna notoriedad y repercusión, como el interpuesto por la Compañía Cervecera del Sur contra la Municipalidad del Cuzco que intentaba cobrarle un "curioso" tributo; la acción promovida por el grupo Vulcano contra la Superintendencia de Banca y Seguros tras la liquidación del Banco de la Industria de la Construcción; así como el amparo del fiscal supremo doctor César Elejalde contra una resolución de la Contraloría.

En materia de Habeas Corpus, incluso existen resoluciones que adoptan criterios inconvenientes para la defensa de los derechos, como el caso interpuesto por Juana Huaracha en favor de 
Héctor Acuache ("El Peruano", 8-10-86) donde el TGC manifiesta que durante el estado de emergencia se suspende la obligación de poner al detenido a disposición del juez dentro de las 24 horas sin que corresponda ningún pronunciamiento jurisdiccional sobre dicha detención; debiendo destacarse el solitario voto del magistrado Aguirre Roca, quien sin llegar a esbozar con claridad la tesis del control judicial de razonabilidad, apunta elementos que sugieren la necesaria revisión que debe efectuar la judicatura para evitar excesos policiales cometidos mediante detenciones arbitrarias favorecidas por la vigencia del estado de emergencia.

Otra resolución que contiene un razonamiento peligroso para la defensa de la libertad personal, es el expuesto en el caso promovido por Angela Horna en favor de Alciblades Díaz ("El Peruano", 7-9-83) quien sufrió detención por orden de un juez, señalando el TGC que como dicha detención no había excedido de 24 horas el Habeas Corpus resultaba improcedente, convalidando con esta tesis cualquier privación de la libertad dispuesta por autoridades judiciales o policiales en tanto no supere las 24 horas, sin merituar la causa que la motiva.

Pero al margen de estos condicionamientos impuestos por el modelo constitucional a la competencia y actuación del TGC, así como de la escasa significación cuantitativa y cualitativa de las causas sometidas a su conocimiento, sería errado no señalar que también ha correspondido una seria responsabilidad al tribunal, por su funcionamiento y la acción de sus magistrados, que ha incidido en la poca gravitación y repercusión de la labor de este órgano en la vida jurídica y la escena política del país.

Ha sido característica muy frecuente en las resoluciones del TGC su extensión excesiva, así como el recurso reiterado e injustificado a numerosos "votos singulares" de los magistrados y "fundamentos adicionales" del fallo en mayoría. Ello empobrece el contenido de la resolución adoptada, privilegiando las opiniones personales de los magistrados, lo que evidencia en muchos casos la ausencia de una voluntad de trabajo conjunto y el fácil rechazo a los intentos de concertar criterios, situación que en mucho fue producto de los conflictos internos que durante buen tiempo 
afectaron las relaciones entre los miembros del TGC. A esto debe sumarse diversos casos donde este tipo de prácticas impidieron al tribunal lograr el número de votos necesarios para dictar sentencia.

Obviamente todo ello ha mellado la imagen pública del TGC, lo que sumado a las limitaciones de orden estructural antes mencionadas, vino a desgastar muy tempranamente la labor de este órgano y a restarle credibilidad sobre su eficacia, al punto que en la actualidad muchos juristas y políticos (incluso algunos de sus propulsores) sostienen la conveniencia de suprimirlo y trasladar sus competencias a una sala constitucional de la Corte Suprema.

Por mi parte, estuve entre quienes no obstante compartir las críticas formuladas a la labor del TGC (al evaluar en 1986 sus primeros tres años y medio de gestión) consideraron necesario tener alguna tolerancia y comprensión hacia el tribunal, pues atendiendo a las serias restricciones que le impuso el modelo constitucional y a lo breve de la experiencia, recomendábamos esperar algún tiempo para que dicha institución pudiera asentarse y madurar. Sin embargo, al cabo de una década de régimen constitucional y de siete años y medio de existencia del TGC, ya es tiempo suficiente para formular una evaluación concluyente, siendo forzoso reconocer -al margen de todas las excusas y explicaciones que puedan darse, y de lo atendibles que algunas puedan resultarque su papel ha sido poco relevante e incluso decreciente, con una casi imperceptible contribución al desarrollo de la constitucionalidad y la democracia en el país.

Considero que sin ampliar el marco competencial que la Constitución atribuye al TGC y adoptar fórmulas que faciliten el acceso más directo ante dicho órgano, su actuación corre el riesgo de seguir diluyéndose cada día, hasta convertirse en claramente prescindible. Con mayor razón si se persiste en propiciar la llegada a esta magistratura de personas que, más allá de sus buenas intenciones, no han podido imprimir al TGC una dinámica creativa y gravitante, ya sea por su dilatada trayectoria profesional, por la falta de la suficiente formación en materia constitucional (indispensable para el buen desempeño de esta labor) o por haber accedido al cargo en base a consideraciones esencialmente políticas y partidarias. 
d) El control de la constitucionalidad de las normas. La acción de inconstitucionalidad ante el TGC, otra de las novedades que trajo la Carta del 79, sólo fue promovida en seis ocasiones en estos diez años y siempre por intermedio de parlamentarios. En ninguno de estos casos se produjo una resolución del tribunal que declare la inconstitucionalidad de la ley cuestionada, pues en tres causas el órgano jurisdiccional falló desestimando las objeciones planteadäs, en dos no alcanzó a dictar sentencia por no reunir el número de votos exigidos para formar decisión, y en un caso la demanda no fue admitida por una deficiencia procesal.

Sin duda que las dos acciones interpuestas contra aspectos de la ley 23903 que reguló las elecciones generales de 1985, fueron las que concitaron mayor interés jurídico y trascendencia política: la primera para cuestionar la consideración como "votos válidamente emitidos" de todos los sufragios, incluyendo los nulos y en blanco, para efectos de la elección presidencial (18); la segunda contra el establecimiento del voto preferencial opcional para los comicios parlamentarios. Puede decirse que esta fue la "prueba de fuego" del TGC en este tipo de acciones, por las implicancias de lo que estaba en juego, pero lamentablemente el tribunal no logró dictar sentencia en ambas causas, pues ninguna de las posiciones en que se agruparon los magistrados alcanzaron el número de votos exigido por ley para hacer decisión. Esta situación, al margen de las explicaciones que puedan esgrimirse, fue otra de las circunstancias que más afectaron la imagen pública del TGC, a sólo dos años de instalado.

En cualquier caso, lo cierto es que la acción de inconstitucionalidad ha tenido escasísima utilización y ninguna eficacia en estos diez años, si nos remitimos al número de causas que fueron promo-

(18) Cfr. VALLE RIESTRA, Javier: El Tribunal de Garantias Constitucionales. El caso de los votos nulos y blancos (1986); GARCIA BELAUNDE, Domingo: Una democracia en transición. Las elecciones peruanas de 1985 (1986); y EGUIGUREN PRAELI, Francisco: La elección presidencial en la Constitución de 1979; Alcances y controversias en el sistema electoral vigente, en Lecturas sobre temas constitucionales 4. 
vidas ante el TGC, pudiendo formularse al respecto algunas conclusiones:

1) E1 acceso al TGC resulta bastante restringido, fundimentalmente por el reducido número de personas e instituciones legitimadas para poder interponer acciones de inconstitucionalidad. De éstas, sólo los parlamentarios y nada más que en seis casos, ante intereses políticos muy coyunturales, han hecho uso de esta atribución, lo cual indica el escaso interés del parlamento y la indiferencia de la Corte Suprema y el Fiscal de la Nación para promover este mecanismo de control constitucional. En cuanto a la posibilidad de que cincuenta mil ciudadanos interpongan una acción de inconstitucionalidad, el hecho que ello no se haya concretado denota que se trata de una exigencia cuantitativa difícil de satisfacer, pero también que no ha existido demasiado interés en utilizarla, pues mecanismos como la acción de amparo (como veremos luego) sirvieron mejor para alcanzar propósitos similares.

2) A partir de esta experiencia, encuentro inconveniente que la Constitución haya restringido a las mismas personas e instituciones la titularidad para interponer una acción de inconstitucionalidad, tanto cuando se trata de leyes y decretos legislativos (que emanan del Congreso y el Poder Ejecutivo) como cuando se dirige contra normas regionales y ordenanzas municipales. Resulta exagerado, por ejemplo, exigir el concurso de cincuenta mil ciudadanos para cuestionar la constitucionalidad de una norma emanada de la asamblea regional o del gobierno municipal; tampoco aparece adecuado haber excluido de toda iniciativa en este campo a instituciones representativas de grupos e intereses sociales (colegios profesionales, gremios empresariales y laborales, etc.). Todo ello ha incidido en la poca utilización de la acción de inconstitucionalidad.

3) El reducido número de acciones interpuestas contrasta con la gran cantidad de veces que, en el debate legislativo o público, diversos grupos políticos o instituciones gremiales (principalmente empresariales) han cuestionado la inconstitucionalidad (real o supuesta, según los casos) de numerosas leyes, sin intentar la acción respectiva ante el TGC. Tal conducta puede deberse, en parte, 
a las dificultades de acceso al TGC o a la poca confianza en su eficacia, pero fundamentalmente obedece al abuso que en estos últimos años se ha hecho del término "inconstitucional", instrumentando este concepto como herramienta para la oposición o el enfrentamiento político coyuntural, y atribuyendo -en muchos casos con demasiada simpleza y falta de solidez jurídica-este carácter a normas que si bien controvertidas desde el punto de vista político, no ostentaban un vicio o conflicto con respecto a la Constitución en la magnitud y sentido que se pretendían.

4) Un hecho importante en los últimos años ha sido la utilización y la distinta interpretación del Poder Judicial con respecto al art. 3o. de la ley 23506, que hace viable el Habeas Corpus y el amparo contra actos $u$ omisiones basados en la ejecución de normas contrarias a la Constitución, debiendo declararse la inaplicación de dicha norma en el mismo proceso. La interpretación que considero más acertada -y que ha sido la más difundida en los especialistas y en el órgano jurisdiccional- estableció que no cabe interponer las acciones de habeas corpus o amparo directamente contra una ley o norma general sino contra sus actos particulares de ejecución, salvo en los casos de leyes de ejecución inmediata o auto aplicativas.

Sin embargo, especialmente a partir de la proliferación de amparos interpuestos directamente contra el proyecto de ley y (luego) la propia ley de estatización del sistema bancario y financiero, diversas resoluciones judiciales (en su mayoría de jueces de primera instancia) acogieron y sentenciaron favorablemente dichas pretensiones, pese a no tratarse de normas auto aplicativas ni de encontrarse aún en vías de ejecución. Ello obviamente con tribuyó al reciente incremento de las acciones de amparo, dirigidas contra leyes, decretos supremos del Poder Ejecutivo o normas generales dictadas por la Administración o los órganos autónomos; influyendo también en la escasa utilización de la acción de inconstitucionalidad y de la acción popular.

No creemos que estas resoluciones (en muchos casos producto de las distorsiones en el amparo antes mencionadas) expresen un criterio definitivo en la orientación de la jurisprudencia hasta 
ahora predominante en el Poder Judicial, pero es de lamentar que no obstante la importancia y repercusión de estos casos, ellos no hayan llegado aún al conocimiento de la Corte Suprema o se encuentren pendientes de resolución, ya sea debido al interés dilatorio de quienes vienen ganando dichos procesos o a la morosidad del aparato judicial. La ausencia de una definición jurisdiccional en la materia, mantiene viva la confusión e incertidumbre, propiciando la continuidad de estas demandas y, en muchos casos, su éxito al menos transitorio.

En cuanto a la acción popular, cabe precisar además que la ausencia de un procedimiento ágil e idóneo desalentó durante años su interposición y le restó toda eficacia, pese a lo cual algunos amparos promovidos contra decretos y normas generales fueron inicialmente desestimados por el Poder Judicial, quien manifestó que la vía adecuada a emplearse era la aludida acción popular. Pero a raíz del exitoso amparo de la Federación de Empleados Bancarios en contra del D.S. 107-85-PCM, que modificó la jornada de trabajo $y$ el horario de verano, resuelto favorablemente por la Corte Suprema el 31-12-86, empezaron a incrementarse las acciones de amparo contra este tipo de normas generales, lo que también incidió en la escasísima utilización de la acción popular.

Finalmente, cabe anotar que la reciente dación de la ley No. 24968 (20-12-88) "Ley procesal de la Acción Popular", sin duda debe propiciar el mejor desarrollo de esta garantía constitucional tan descuidada entre nosotros. Esta ley trae aportes positivos e importantes novedades, tales como el establecer que dicha acción puede ser interpuesta por cualquiera, el alcance general de la sentencia que declare la inconstitucionalidad o ilegalidad de la norma cuestionada, así como el diseño de un procedimiento más rápido y adecuado. El tiempo de aplicación y la difusión de esta norma son aún insuficientes, por lo que habrá que esperar antes de evaluar su funcionamiento y eficacia. Lo que si cabe es desear que al fin la acción popular deje de ser esa suerte de garantía devaluada que tanto afectó su uso y vigencia. 


\subsection{SUBVERSION, POLITICA ANTISUBVERSIVA Y ESTADO DE EMERGENCIA}

A consecuencia de la acción armada subversiva emprendida por el PCP "Sendero Luminoso" en la zona de Ayacucho, el gobierno de Fernando Belaunde declaró en octubre de 1981 en estado de emergencia varias provincias de dicho departamento; poco después esta situación abarcó también a localidades de los departamentos de Apurímac y Huancavelica. El incremento de la violencia determinó que dicho gobierno, en diciembre de 1982, dispusiera que las Fuerzas Armadas asumieran la conducción de la lucha antisubversiva en la región, conformándose desde entonces, y hasta la actualidad, una "zona de emergencia" sujeta a control militar.

Posteriormente, en forma paulatina, la acción violentista se fue extendiendo a otras zonas del pais, originando la simultánea presencia de fuerzas militares y policiales en las localidades afectadas, al punto de que al cumplirse diez años de régimen constitucional se encuentran sometidas al estado de emergencia amplias zonas del territorio nacional, como Ayacucho, Huancavelica, Apurímac, Junín, Cerro de Pasco, San Martín, Huánuco y Puno; encontrándose inclusive Lima y Callao en esta situación desde febrero del 86. En suma, casi la mitad de la población del país se halla bajo el régimen de excepción.

Pero la violencia armada se ha acrecentado, pues a la actividad del PCP-SL se han sumado otros grupos como el MRTA, así como también han surgido comandos para-militares de derecha dedicados a la amenaza y asesinato de dirigentes de izquierda o de personas presuntamente vinculadas a la acción subversiva; a la vez, en diversas zonas de San Martín y Huánuco existen actos violentos propiciados por grupos ligados al narcotráfico. A ello tenemos que agregar los efectos de la lucha antisubversiva que realizan las fuerzas del orden, en cuyo ejercicio se ha recurrido con frecuencia a prácticas violatorias de los derechos humanos (la denom inada "guerra sucia'), a la incorporación organizada de grupos de la población civil (campesina) para que participen en acciones armadas. Todo este fenómeno de violencia ha acarreado el saldo de muerte y destrucción al que ya nos hemos referido, asi como una profun- 
da restricción a la vigencia de los derechos y libertades, en el marco de un estado de emergencia prolongado que coexiste al interior de un régimen constitucional y democrático.

El rasgo característico de la estrategia gubernamental frente al fenómeno subversivo, ha sido el limitarse - casi exclusivamentea la respuesta militar y represiva, encomendando esta responsabilidad a las fuerzas armadas y policiales mientras que las autoridades políticas han optado mayormente por desentenderse de lo esencial del enfrentamiento al problema. Los iniciales anuncios del gobierno aprista de acompañar la acción militar antisubversiva con medidas de tipo social, económico y político para atender a las zonas desvastadas por la violencia, muy pronto fueron abandonados, pese a que importantes representantes de las fuerzas armadas, de la Iglesia y de instituciones protectoras de los derechos humanos, han manifestado la necesidad de una estrategia in tegral y la inviabilidad de la respuesta estrictamente militar para avanzar en la pacificación del país y poner fin a la violencia que hoy nos aqueja.

De allí que al evaluar esta permanencia prolongada de los estados de emergencia y el resultado de la acción antisubversiva frente al fenómeno de la estrategia gubernamental - de corte esencialmente militar y represivo- ha fracasado rotundamente y deteriorado la legitimidad y eficacia del régimen constitucional. Esta afirmación se sustenta en las constataciones siguientes (19):

a) La represión militar no ha logrado acabar con la acción armada subversiva y terrorista, pese que a ella se han destinado grandes recursos económicos y que la lucha ha causado más de $15 \mathrm{mil}$ muertos en la población civil, los grupos subversivos y las fuerzas del orden. Tampoco ha impedido que la presencia de los grupos subversivos subsista en la región de Ayacucho y la sierra central, no obstante que dicha zona se encuentra en estado de emergencia

(19) Cfr. EGUIGUREN PRAELI, Francisco: El estado de emergencia y su aplicación en la experiencia constitucional peruana 1980-88; en La Constitución diez años después (varios autores); Instituto Constitución y Sociedad y Fund. F. Neumann (julio 89). 
ininterrumpido por más de 8 años, ni que esta acción se extienda a amplias y diversas áreas del país, comprometiendo incluso a $\mathrm{Li}$ ma y zonas aledañas.

b) Los grupos subversivos han logrado, mediante asesinatos y amenazas, la vacancia de todo tipo de autoridades políticas, municipales y judiciales en diversas zonas rurales del país, asi como la desaparición de la actividad de dependencias y funcionarios estatales. La presencia del Estado, allí donde existió tenuemente, se ha ido diluyendo en dichas localidades por una suerte de repliegue, situación a la que no escapan las fuerzas policiales que han tenido que abandonar muchos puestos destruidos o a tacados por la acción armada subversiva. Y en aquellas zonas donde este vacío dejado por el aparato estatal ha pretendido ser llenado por las autoridades militares, como es el caso del Comando Político-Militar instaurado en la zona de emergencia, su propia naturaleza castrense, la acción fundamentalmente represiva y la carencia de atribuciones para adoptar medidas políticas y sociales - que corresponden al gobierno- han mantenido irresuelta la situación de violencia y sin restablecer la normalidad administrativa y política de la región.

c) Lo prolongado de la lucha antisubversiva, su crueldad, las muertes causadas por los grupos subversivos y la certeza de que la respuesta militar no conduce a solución alguna, han generado un desgaste y exasperación en las fuerzas armadas y policiales que han ocasionado numerosos crímenes y excesos represivos en contra de la población civil. La pasividad gubernamental, frente a estas conductas inaceptables dentro de un régimen democrático, y el sometimiento de numerosos casos denunciados ante el Fuero Militar, trajeron como resultado la virtual impunidad para muchos de los autores de actos excecrables en agravio de los derechos humanos, así como la falta de una voluntad política de poner fin y sancionar a dichas prácticas.

Esta complacencia de las principales autoridades de ambos gobiernos constitucionales frente a comprobados casos de violación a los derechos humanos, no sólo ha cuestionado su legitimidad dentro y fuera del país; también ha acentuado el descontento de la población hacia las fuerzas armadas y policiales, así como frente 
al sistema democrático. No puede desconocerse un hecho tan preocupante como la imposibilidad de realizar elecciones en diversas localidades rurales del país, sujetas al estado de emergencia y al control militar, ya sea por ausencia de candidatos o de electores, o porque los comicios tuvieron que anularse al comprobarse que más de dos tercios de los votos fueron nulos o en blanco, lo que evidencia una clara opción popular de rechazo, protesta y escepticismo.

d) Al amparo del estado de emergencia, sobre todo en las zonas apartadas, se han restringido y vulnerado muchos más derechos de los cuatro que establece la Constitución para esta situación; incluso en el caso de la libertad personal, que puede limitarse durante el régimen de excepción, se han perpetrado grandes arbitrariedades y detenciones injustificadas por las fuerzas del orden (siendo también Lima un buen ejemplo de ello) sin que, por lo general, las autoridades judiciales hayan asumido un papel contralor y correctivo ante tales conductas.

Pero además se han producido algunos casos verdaderamente dramáticos y condenables, que demuestran a los extremos que se ha llegado en la represión antisubversiva y en la aplicación del estado de emergencia. Un caso lo constituyó el aniquilamiento de los internos encausados por terrorismo amotinados en los penales de Lurigancho y la isla El Frontón (en Lima y Callao) el 18 y 19 de junio del $86(20)$. Mediante un decreto supremo aprobado por el gobierno. se adoptó una decisión inconstitucional que declaró a los penales como "zona militar restringida" y substrajo indebidamente de la jurisdicción civil (Fuero Común y Ministerio Público) el conocimiento y juzgamiento de los delitos cometidos en el debelamiento de los motines: esta crrada medida política y su ejecución aún más apresurada, dieron como resultado el uso irracional y desproporcionado de la fuerza represiva y la actuación criminal de al-

(20) Cfr. Informe al Congreso de los suciesos de los Penales, presentado por el senador Rolando Ames (presidente de la comisión investigadora) y otros cinco parlamentarios (1988). Asimismo, Los sucesos de los penales: nueva abdicación de la autoridad denocratica. Un enfoque juridico. Carlos Chipoco, Francisco Eguiguren y Miguel Talavera; Instituto de Defensa Legal (1.986). 
gunos miembros de las instituciones militares y policiales, que culminaron con el asesinato de más de 300 reclusos, la mayor parte de ellos exterminados cuando se hallaban inermes y rendidos.

El gobierno aprista ocultó inicialmente estos hechos y los delitos cometidos; algunos de los autores de estos actos ilícitos vienen siendo juzgados ante el Fuero Militar, sin que hasta el momento hayan sido sancionados los principales responsables. El carácter inconstitucional del decreto aprobado por el Presidente y el Consejo de Ministros, los hace pasibles de responsabilidad penal y constitucional que podría dar lugar (según han anunciado diversos grupos políticos) a una acusación a presentarse en la Cámara de Diputados durante el próximo gobierno.

\section{A MANERA DE CONCLUSION:}

Al cumplirse estos primeros diez años de régimen constitucional, resulta forzoso reconocer que el modelo político democrático previsto en la Carta de 1979 , especialmente en cuanto a su propuesta de una democracia social basada en el desarrollo y vigencia de una amplia y progresista relación de derechos y garantías constitucionales, ha tenido más bien una aplicación insuficiente y bastante distante del logro de avances sustantivos en la sat tisfacción de las grandes aspiraciones populares expresadas en la Constitución.

Es verdad que se han producido algunos logros positivos, como el afianzamiento de la continuidad democrática mediante la realización de procesos electorales, que han permitido la instalación y culminación del mandato de dos gobiernos surgidos del sufragio popular: ello, a su vez, posibilitará en breve la elección de un tercer gobierno consecutivo emanado de la voluntad del pueblo. Asimismo, los cuatro procesos electorales municipales y la progresiva conformación de los gobiernos regionales, han ampliado la participación de los ciudadanos en la selección de sus representantes politicos para el gobierno a nivel local, regional y nacional.

Pero el tiempo transcurrido ha servido también para confirmar las observaciones que desde un principio se formularon a este modelo de democracia representativa plasmado en la Carta, sobre 
todo por su carácter estrictamente electoral que excluye la participación popular en la formación y adopción de todo tipo de decisiones políticas, así como en el control de la actuación de los representantes. Ello se puso de manifiesto, por ejemplo, cuando los gobiernos de Acción Popular y el APRA (ambos nacidos con un importante respaldo popular) empezaron a experimentar un serio $\mathrm{e}$ incontenible deterioro en sus niveles de popularidad y legitimidad desde mediados de sus mandatos; las amplias derrotas sufridas por ambos partidos en las elecciones municipales realizadas en el tramo final de sus respectivos gobiernos confirman esta situación.

Sin embargo, la ausencia de mecanismos que permitan modificar o renovar la composición política del parlamento o, cuando menos, de medios eficaces de presión popular que induzcan al cambio de las políticas gubernamentales y del comportamiento de las mayorías parlamentarias que ambos gobiernos ostentaron en el Congreso, posibilitaron que prevalecieran la insensibilidad y desatención de estos dos regímenes ("democráticos") frente al cuestionamiento de que era objeto su gestión, lo que contribuyó a acentuar el aislamiento popular y el desprestigio que acompañaron a estos gobiernos durante buena parte de sus mandatos.

Otro aspecto que ha venido conspirando contra la legitimidad y el adecuado funcionamiento del régimen constitucional, es la carencia de autoridades políticas y civiles que padecen algunas localidades (principalmente rurales) convulsionadas por la violencia subversiva, sujetas a control militar y estados de emergencia prolongados, situación que en Ayacucho y zonas aledañas persiste por más de ocho años. Allí no sólo han habido dificultades para realizar procesos electorales. sea por ausencia de candidatos o de electores, ante las amenazas y asesinatos perpetrados por los grupos subversivos: lo grave es que existen casos donde tras realizarse los comicios, éstos tuvieron que anularse al constatar que más de dos tercios de los votos resultaron nulos o en blanco, signo evidente del descontento popular frente al orden vigente y de su escepticismo ante el proceso electoral como posible solución a sus problemas.

Si esta situación se extendiera a otras zonas del territorio nacional, en las cuales ya se vive la violencia subversiva y la repre- 
sión militar dispuesta por ambos gobiernos, se corre el gravísimo riesgo de la progresiva militarización del país, del enfrentamiento incontrolado entre grupos armados de la población civil, así como del funcionamiento parcial e ineficaz de los sistemas de representación política y participación electoral. Y es que si bien no puede identificarse ni circunscribirse a la democracia como simple elección periódica de representantes o gobernantes, mal puede pensarse en un desarrollo democrático allí donde ni siquiera la realización de elecciones resulta posible.

En definitiva, a lo largo de estos diez años de régimen constitucional ambos gobiernos son responsables de haber optado por una respuesta esencialmente represiva y militar, del todo ineficaz para solucionar la situación de violencia generada a partir de la acción armada desatada por grupos subversivos, así como incapaz de contribuir a la pacificación del país. La persistencia de la acción subversiva, la vigencia prolongada de los estados de emergencia y su extensión real (declarada o no) a amplias zonas del territorio nacional, vienen causando un creciente proceso de recorte y violación de los derechos ciudadanos y la desaparición de manifestaciones políticas indispensables de la vida democrática.

La errada estrategia gubernamental exclusivamente militar, que ha abdicado de las funciones y responsabilidades que le corresponden en un sistema constitucional, ha acrecentado la dependencia de las principales autoridades políticas frente a los mandos e instituciones castrenses, lo que se ha traducido en la pasividad o encubrimiento de numerosos casos de excesos represivos y violación de derechos humanos, generando una complicidad y falta de propósito de enmienda ante tales prácticas, que socavan la legitimidad política, jurídica y moral de quienes ejercen la conducción del régimen democrático.

Tampoco se han producido avances significativos en cuanto al respeto y vigencia de la libertad personal, al margen de las naturales mejoras que se producen al pasar de un gobierno de facto a un régimen constitucional. Y es que si bien la Constitución limitó las causas por las cuales una persona puede ser privada de su libertad por acción de la policía (cuando existe una orden judicial o la 
captura se produce en flagrante delito) lo cierto es que han proseguido antiguas prácticas de las autoridades políticas y policiales que persisten en realizar detenciones en casos que ya no están permitidos en la norma constitucional.

A menudo, la situación de violencia y la continuidad prolongada de los estados de emergencia han propiciado que los atropellos contra la libertad individual no sólo se limiten a frecuentes detenciones arbitrarias; éstas suelen ir acompañadas de atentados contra la in tegridad personal (maltratos y torturas) y de no pocos casos de pérdida de la vida en agravio de la población civil (fundamentalmente campesina) mediante actos tales como las detencionesdesapariciones y las ejecuciones extra judiciales perpetradas por miembros de las fuerzas de seguridad, o los asesinatos de pobladores y autoridades cometidos por los grupos subversivos.

Es de lamentar que las autoridades judiciales, sea por la precariedad e inseguridad que padecen en las zonas convulsionadas por la violencia, como por la pasividad y complacencia que han evidenciado en otros lugares, se hayan mostrado - en la mayoría de casos- incapaces para corregir estos excesos y controlar la actuación de las fuerzas del orden. La escasa eficacia de la acción de Habeas Corpus evidencia dicha inoperancia judicial, así como la alarmante violación que crecientemente sufren los derechos a la libertad e integridad personal y a la vida.

En cuanto a la acción de amparo, resulta indudable que su incorporación constitucional ha resultado positiva para la mejor protección de los derechos, pese a las serias distorsiones que se produjeron en su utilización, así como a la reciente instrumentación política de que ha sido objeto, especialmente por acción de grupos económicos poderosos en favor de sus intereses patrimoniales. La reforma introducida en el amparo, con relación a la medida cautelar de suspensión provisional del acto reclamado, atenta seriamente contra su eficacia, siendo deseable que ésta sea plenamente restablecida, para lo cual será fundamental una actuación meditada y sensata de los jueces.

En cambio, la utilización de la acción de inconstitucionalidad 
y la acción popular ha resultado realmente escasa, pudiendo esperar en el caso de esta última que su uso se acreciente a raíz de la ley procesal dictada no hace mucho sobre la materia. Y en cuanto a la actuación del Tribunal de Garantías Constitucionales, cabe decir que su papel ha sido más bien discreto, resultando su gravitación en la vida política y jurídica del país cada vez menos perceptible.

Mención especial merecen los derechos económicos y sociales recogidos en la Constitución del 79 , pues su desarrollo y vigencia resultaban fundamentales para alcanzar la democracia avanzada y el modelo de Estado Social y Democrático de Derecho plasmados en dicha Carta. Ya dijimos que poco o nada se ha conseguido en este campo al cumplirse diez años de régimen constitucional, tanto por efecto de la severa crisis económica derivada de las erradas politicas gubernamentales, como por la ausencia de una voluntad verdaderamente dispuesta a realizar las transformaciones y adoptar las medidas que hagan posible alcanzar algunos logros concretos.

No es por ello casual que luego de diez años de régimen constitucional y en el inicio de la última década de este siglo, el eje fundamental del debate electoral que hoy vive el país esté puesto en la necesidad de definir el rol del Estado en la actividad económica, su grado de intervención y el carácter de su participación para alcanzar el desarrollo y el bienestar, así como la satisfacción de los derechos económicos y sociales proclamados en la Constitución. La relativa amplitud de interpretación y posibilidades de aplicación que fluyen del Régimen Económico plasmado en la Carta, hacen mas atractivo y polémico este debate, con una intensidad que no tuvo mayormente al redactarse el texto constitucional ni durante los primeros años de su vigencia.

Lo medular del tema radica en determinar cual es la mejor forma de avanzar en el desarrollo de estos derechos: si mediante una intensa intervención estatal en la economía, bajo la orientación política socialista ; o a través de una regulación estatal significativa pero moderada, propia de las opciones del llamado Estado Social de Derecho; o más bien bajo una conducción neoliberal que restrinja al mínimo la injerencia del Estado en la actividad econó- 
mica y encomiende al mercado la asignación de recursos y la satisfacción de las necesidades sociales. Lo cierto es que el próximo régimen constitucional estará signado por este debate político e ideológico, así como por las opciones que se adopten en relación a la atención de los derechos económicos y sociales, sin perjuicio de las estrategias que se sigan frente a problemas como la subversión, la violencia y la crisis económica, que según todo parece indicar nos continuarán acompañando aún por buen tiempo.

Así como la realización del elecciones no basta por si sola para hacer a una sociedad democrática, menos aún puede pensarse que con ello y un nuevo gobierno se solucionan todos los problemas y las dificultades. En una sociedad subdesarrollada y dependiente como la peruana, con profundas injusticias y desigualdades a las que hoy se suman la acción subversiva y la violencia generalizada, dudo mucho en verdad que la propuesta neoliberal, con su apuesta ciega al mercado, la iniciativa privada y al sistema capitalista, sea capaz de alcanzar la pacificación del país y propiciar el desarrollo espontáneo de los derechos económicos y sociales recogidos en nuestra Constitución.

Por ello considero que el positivo avance que estos diez años de continuidad del régimen constitucional conllevan para el afianzamiento de la democracia, resulta insuficiente si se prescinde de la realización de profundas transformaciones sociales, que alteren las relaciones de propiedad, poder económico y político imperantes en el pais. Renunciar a la necesidad de cfectuar estos cambios, puede equivaler a descargar la posibilidad de construir una socicdad de paz y justicia social, elementos esenciales de toda propuesta sinceramente democrática.

Sobre todo cuando la persistencia prolongada de esta distancia entre el modelo recogido en nuestra Constitución y sus niveles de avance o aplicación concreta en la realidad, genera el riesgo de terminar destruyendo la ilusión popular de construir y alcanzar finalmente, por el camino del régimen constitucional, una sociedad democrática, pese a que se la perciba como una promesa aún lejana. Y con ello se estaría empujando a la población a abandonar este arduo esfuerzo. al asumir a dicho modelo como una simple e 
inútil farsa, por efecto de su negación cotidiana y su falta de viabilidad política.

Lima, marzo de 1990 